\title{
ACPD
}

13, 16885-16924, 2013

This discussion paper is/has been under review for the journal Atmospheric Chemistry and Physics (ACP). Please refer to the corresponding final paper in ACP if available.

\section{Global stratospheric fluorine inventories for 2004-2009 from Atmospheric Chemistry Experiment Fourier Transform Spectrometer (ACE-FTS) measurements}

A. T. Brown ${ }^{1}$, M. P. Chipperfield ${ }^{2}$, N. A. D. Richards ${ }^{2}$, C. Boone ${ }^{3}$, and P. F. Bernath ${ }^{4,5}$

${ }^{1}$ Department of Physics, University of York, Heslington, YO10 5DD, UK

${ }^{2}$ Institute for Climate and Atmospheric Science, School of Earth and Environment, University of Leeds, Leeds, LS2 9JT, UK

${ }^{3}$ Department of Chemistry, University of Waterloo, Waterloo, Ontario, Canada

${ }^{4}$ Department of Chemistry and Biochemistry, Old Dominion University, Virginia, USA

${ }^{5}$ Department of Chemistry, University of York, Heslington, YO10 5DD, UK

Received: 4 April 2013 - Accepted: 3 June 2013 - Published: 25 June 2013

Correspondence to: A. T. Brown (alex.brown@york.ac.uk)

Published by Copernicus Publications on behalf of the European Geosciences Union.

Global stratospheric fluorine inventories for 2004-2009

A. T. Brown et al.

Title Page 


\section{Abstract}

Fluorine-containing species can be extremely effective atmospheric greenhouse gases. We present fluorine budgets using organic and inorganic species retrieved by the ACEFTS satellite instrument supplemented with output from the SLIMCAT 3D chemical 5 transport model. The budgets are calculated between 2004 and 2009 for a number of latitude bands: $70-30^{\circ} \mathrm{N}, 30-0^{\circ} \mathrm{N}, 0-30^{\circ} \mathrm{S}$, and $30-70^{\circ} \mathrm{S}$. At lower altitudes total fluorine profiles are dominated by the contribution from CFC-12, up to an altitude of $20 \mathrm{~km}$ in the extra-tropics and $29 \mathrm{~km}$ in the tropics, above these altitudes the profiles are dominated by HF. Our data show that total fluorine profiles at all locations have a negative slope with altitude, providing evidence that overall fluorine emissions (measured by their $\mathrm{F}$ content) have been increasing with time. Total stratospheric fluorine is increasing at a similar rate in the tropics; $32.5 \pm 4.9 \mathrm{ppt} \mathrm{yr}^{-1}(1.31 \pm 0.20 \%$ per year $)$ in the Northern Hemisphere $(\mathrm{NH})$ and $29.8 \pm 5.3 \mathrm{ppt} \mathrm{yr}^{-1}(1.21 \pm 0.22 \%$ per year) in the Southern Hemisphere (SH). Extra-tropical total stratospheric fluorine is also increasing at a similar rate in both the $\mathrm{NH}$ and $\mathrm{SH} ; 28.3 \pm 2.7$ ppt per year $(1.12 \pm 0.11 \%$ per year) in the $\mathrm{NH}$ and $24.3 \pm 3.1$ ppt per year $(0.96 \pm 0.12 \%$ per year $)$ in the $\mathrm{SH}$. The volume mixing ratio of each species used in this study was weighted by its global warming potential (GWP), relative molecular mass and the atmospheric pressure to produce a GWP-weighted total fluorine trend. These trends show mean changes of $0.02 \pm 0.08 \%$ per year in the $\mathrm{NH}$, and $0.07 \pm 0.05 \%$ per year in the $\mathrm{SH}$. Overall, GWP-weighted fluorine remains roughly constant globally. However, the decreasing trends in the mixing ratios of halons and CFCs, due to their prohibition under the Montreal Protocol, have suppressed an increase in total fluorine caused by increasing mixing ratios of HFCs. This has reduced the impact of fluorine containing species on global warming.
ACPD

13, 16885-16924, 2013

Global stratospheric

fluorine inventories for 2004-2009

A. T. Brown et al.

Title Page

Abstract

Introduction

Conclusions

References

Tables

Figures

14

$\rightarrow 1$

4

Back

Close 


\section{Introduction}

Many fluorine-containing chemicals are widely used in industry and elsewhere because they are chemically inert, non-toxic and odourless. A number of fluorine-containing species are controlled under the Montreal Protocol (UNEP, 2009) because they are

5 ozone depleting substances. Whilst fluorine atoms do not play a direct part in ozone loss, many of the species, such as chlorofluorocarbons (CFCs) and hydrochlorofluorocarbons (HCFCs) also contain chlorine and so do contribute to ozone loss. The $\mathrm{C}-\mathrm{F}$ bonds in these molecules typically absorb infrared radiation between 1000 and $1300 \mathrm{~cm}^{-1}$ (Lide, 1990); a "window" region in which the atmosphere is almost transparent. At wavenumbers below $1000 \mathrm{~cm}^{-1}$ incoming radiation is absorbed by $\mathrm{CO}_{2}$ and $\mathrm{H}_{2} \mathrm{O}$, at wavenumbers above $1400 \mathrm{~cm}^{-1}$ incoming radiation is absorbed by $\mathrm{CH}_{4}$ and $\mathrm{H}_{2} \mathrm{O}$. Fluorine-containing species are therefore very powerful greenhouse gases and as such their emissions are limited under the Kyoto Protocol (Solomon, 2007). The global warming potentials (GWPs) (on a $20 \mathrm{yr}$ timeframe) of some of the species used

in this work are shown in Table 1. Many fluorine containing species such as CFCs and hydrofluorocarbons (HFCs) are very stable and inert, thus they have extremely long atmospheric lifetimes. For example, HFC-23 has a $100 \mathrm{yr}$ global warming potential of 14800 relative to that of $\mathrm{CO}_{2}$. Long-term monitoring of these species is therefore important for climate prediction. Fluorine budgets are useful metrics for checking the atmospheric chemistry of fluorine containing species. Previously fluorine budgets have used changes in the VMR of total fluorine as a proxy for changes in VMR of chlorine since many of these species contained both fluorine and chlorine containing species (Nassar et al., 2006b). In recent years, with the increased emissions of HFCs and decreases in purely chlorine containing species such as $\mathrm{CCl}_{4}$ and $\mathrm{CH}_{3} \mathrm{CCl}_{3}$, this approach can no longer be used. However, coupled with stratospheric chlorine budgets the total fluorine calculation allows the effects of the Montreal Protocol to be quantified, with chlorine-containing species being replaced by fluorine-containing species.
Global stratospheric fluorine inventories for 2004-2009

A. T. Brown et al.

Title Page
Abstract

Conclusions

Tables

14

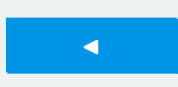

Back
Introduction

References

Figures

$\rightarrow 1$

Close
Full Screen / Esc

Printer-friendly Version

Interactive Discussion 
A number of fluorine budgets have been calculated previously. Measurements made by the Atmospheric Trace MOlecule Spectroscopy (ATMOS) instrument were used to calculate a stratospheric fluorine budget using VMR profiles of $\mathrm{CF}_{4}, \mathrm{CFC}-11, \mathrm{CFC}-12$, $\mathrm{COF}_{2}, \mathrm{HCFC}-22, \mathrm{HF}$ and $\mathrm{SF}_{6}$ at $30^{\circ} \mathrm{N}$ for 1985 (Zander et al., 1992). Further work was 5 carried out using the Jet Propulsion Laboratory's MkIV balloon-borne Fourier Transform Spectrometer retrievals of $\mathrm{CF}_{4}$, CFC-11, CFC-12, CFC-113, COF $2, \mathrm{HCFC}-22, \mathrm{HF}$ and $\mathrm{SF}_{6}$ (Sen et al., 1996). The most recent fluorine budget was carried out using data from the Atmospheric Chemistry Experiment Fourier Transform Spectrometer (ACEFTS) (Nassar et al., 2006b). This budget used version $2.2 \mathrm{ACE}-\mathrm{FTS}$ retrievals of $\mathrm{CF}_{4}$, 10 CFC-11, CFC-12, CFC-113, COCIF, COF 2 , HCFC-22, HCFC-142b, HFC-134a, HF and $\mathrm{SF}_{6}$. When considered together these works show increasing stratospheric fluorine volume mixing ratios between 1985 and 2004. Total column measurements of $\mathrm{COF}_{2}$ and HF from ground-based Fourier Transform Infra-red Spectrometers (FTIR) showed stratospheric fluorine increased at a rate of $0.4 \%$ per year between 2005 and 2008 15 (WMO, 2011). Ground-based FTIR measurements from Kiruna, Sweden show that the HF column increased at a rate of $1.0 \pm 0.3 \%$ per year between 1996 and 2008 (Mikuteit, 2008).

This paper presents fluorine budgets calculated from ACE-FTS measurements supplemented with output from the SLIMCAT 3D Chemical Transport Model (CTM). The budgets have been calculated using 18 fluorine-containing species (lists of which are given in Sect. 3), and represents the most comprehensive fluorine budget in the upper atmosphere to date. These budgets were calculated in 4 latitude bands between $70^{\circ} \mathrm{N}$ and $70^{\circ} \mathrm{S}$. The ACE-FTS instrument has been active since 2004 and we are therefore able to chart the long-term changes in atmospheric volume mixing ratios (VMR) of fluorine-containing species during this time. As such an individual fluorine budget has been calculated for every year from 2004 to 2009. The large number of fluorinecontaining species used in this work allows the calculation of the total fluorine VMR. Previous studies from ACE data from this period have shown that the rate of decrease in the VMRs of CFC-11, CFC-12 and CFC-113 is significantly smaller than the rate
Global stratospheric fluorine inventories for 2004-2009

A. T. Brown et al.

Title Page
Abstract

Conclusions

Tables

14

4

Back
Introduction

References

Figures

$\rightarrow$

Close
Full Screen / Esc

Printer-friendly Version

Interactive Discussion 
of increase in the VMRs of the 3 most common HCFCs, HCFC-22, HCFC-141b and HCFC-142b (Brown et al., 2011). The effect that these changes in the atmospheric VMRs of particular species will have on the total fluorine budget will be dependent on the number of fluorine atoms contained by each species. The GWP weighted trends

5 in total fluorine are also presented and illustrate how changes in atmospheric fluorine have affected climate forcing.

Section 3 gives a brief description of ACE and a discussion on the validation of fluorine-containing species retrieved by ACE. A brief description of the SLIMCAT 3D Chemical Transport Model (CTM) (for a full description of the model readers are di10 rected to Chipperfield, 2006) is given in Sect. 4 and stratospheric fluorine chemistry is discussed in Sect. 5. Section 6 outlines our method for calculating the fluorine budget. The results of this work are presented and discussed in Sect. 7.

\section{The Atmospheric Chemistry Experiment}

Designed to study "the chemical and dynamical processes that control the distribu15 tion of ozone in the stratosphere and upper troposphere" (Bernath, 2006), the Atmospheric Chemistry Experiment (ACE) Fourier Transform Spectrometer (FTS) was launched on board the satellite SCISAT-1 in August 2003. SCISAT-1's orbit, a low circular orbit with an inclination of $74^{\circ}$ (Bernath et al., 2005), gives ACE-FTS almost global coverage from the Antarctic to the Arctic. ACE's primary instrument is a high20 resolution $\left(0.02 \mathrm{~cm}^{-1}\right)$ FTS which operates between 750 and $4400 \mathrm{~cm}^{-1}$. The sun acts as a source of infra-red radiation allowing ACE-FTS to record transmission spectra of the limb of the atmosphere at a series of tangent heights during sunrise and sunset. Using the retrieval methods outlined by Boone et al. (2005), version 3.0 of the ACE retrieval currently produces atmospheric profiles of over 30 molecules from ACE-FTS spectra (http://www.ace.uwaterloo.ca). The ACE-FTS is in its tenth year of operation with routine data being available from February 2004.

Global stratospheric

fluorine inventories for 2004-2009

A. T. Brown et al.

Title Page

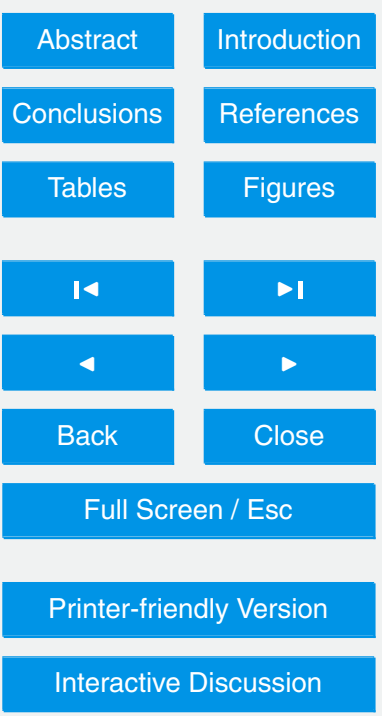


The ACE-FTS currently measures 8 fluorine-containing species, $\mathrm{CF}_{4}, \mathrm{CFC}-12$ $\left(\mathrm{CCl}_{2} \mathrm{~F}_{2}\right), \mathrm{CFC}-11\left(\mathrm{CCl}_{3} \mathrm{~F}\right), \mathrm{COF}_{2}$, COCIF, HCFC-22 $\left(\mathrm{CHF}_{2} \mathrm{Cl}\right), \mathrm{HF}$ and $\mathrm{SF}_{6}$ with version 3.0 retrievals and $9 \mathrm{yr}$ of data (2004-2012; version 3.0 has some problems after September 2010). The retrieval limits of these species are shown in Table 2. Ver5 sion 3.0 also has retrievals for CFC-113 $\left(\mathrm{C}_{2} \mathrm{Cl}_{3} \mathrm{~F}_{3}\right)$, HCFC-142b $\left(\mathrm{C}_{2} \mathrm{H}_{3} \mathrm{ClF}_{2}\right)$, HCFC141b $\left(\mathrm{C}_{2} \mathrm{H}_{3} \mathrm{Cl}_{2} \mathrm{~F}\right)$ (Brown et al., 2011) and HFC-23 $\left(\mathrm{CHF}_{3}\right)$ (Harrison et al., 2012), but the retrieved concentrations have substantial biases so it was decided to use model data instead. ACE data was supplemented with output from the SLIMCAT 3D chemical transport model for CFC-113, CFC-114, CFC-115, H-1211, H-1301, HCFC-141b, HCFC-142b, HFC-23, HFC-134a and HFC-152a.

\subsection{Fluorine containing species retrieved by the Atmospheric Chemistry Experiment}

\subsubsection{Carbon Tetrafluoride $-\mathrm{CF}_{4}$}

$\mathrm{CF}_{4}$ is a powerful greenhouse gas (see Table 1) which has a lifetime of over $2300 \mathrm{yr}$, 15 the emissions of which are primarily from aluminium production. First retrieved from ACE-FTS data for the stratospheric fluorine budget (Nassar et al., 2006b), the ACEFTS retrieval was validated by comparison with non-coincident Mk-IV balloon profiles. This study found that profiles from Mk-IV and ACE were within $\pm 10 \%$ (Velazco et al., 2011).

\subsubsection{Sulphur Hexafluoride - $\mathrm{SF}_{6}$}

$\mathrm{SF}_{6}$ is used as an electrical insulating gas in power distribution equipment and as an inert chemical tracer. The long lifetime of $3200 \mathrm{yr}$ and strong infrared absorption cross sections in an atmospheric window region near $950 \mathrm{~cm}^{-1}$, are responsible for making this molecule a potent greenhouse gas. ACE-FTS retrievals of $\mathrm{SF}_{6}$ were validated by

Global stratospheric fluorine inventories for 2004-2009

A. T. Brown et al.

Title Page

Abstract

Introduction

Conclusions

Tables

References

Figures

14

$\rightarrow 1$

4

Back

Close

Full Screen / Esc

Printer-friendly Version

Interactive Discussion 
comparison with non-coincident Mk-IV balloon profiles. This study found that an agreement within $\pm 15 \%$ between 12 and $19 \mathrm{~km}$ (Velazco et al., 2011).

\subsubsection{CFC-11- $\mathrm{CCl}_{3} \mathrm{~F}$}

13, 16885-16924, 2013

CFC-11 is banned under the Montreal Protocol and is the second most abundant CFC 5 in the atmosphere. Validation of ACE-FTS retrievals were carried out using the FIRS2 instrument. These comparisons showed an agreement to within $10 \%$ below $16 \mathrm{~km}$ (Mahieu et al., 2008). Comparisons between ACE and Mk-IV profiles show agreement to $10 \%$ above $12 \mathrm{~km}$ and $20 \%$ below $12 \mathrm{~km}$ (Mahieu et al., 2008). Non-coincident MkIV balloon profiles were also used for validation, producing differences of less than $10 \pm 20 \%$ between $17 \mathrm{~km}$ and $24 \mathrm{~km}$ (Velazco et al., 2011).

\subsubsection{CFC-12- $\mathrm{CCl}_{2} \mathrm{~F}_{2}$}

CFC-12 is the most abundant CFC in the atmosphere and is banned under the Montreal Protocol. ACE-FTS retrievals were compared to FIRS-2 measurements showing an agreement to $10 \%$ above $12 \mathrm{~km}$ and $20 \%$ below $12 \mathrm{~km}$ (Mahieu et al., 2008). Non-

coincident retrievals from ACE-FTS were compared to measurements from Mk-IV instrument. This study also found differences of around $\pm 10 \%$ (Velazco et al., 2011).

\subsubsection{HCFC-22 - $\mathrm{CHCIF}_{2}$}

HCFCs are transitional replacement compounds for CFCs under the Montreal Protocol. HCFC-22 is the most abundant HCFC in the atmosphere as it has been widely used since the 1950s. The HCFC-22 retrieval used in this paper is new; a paper is currently under preparation which discusses this new retrieval.

Global stratospheric

fluorine inventories for 2004-2009

A. T. Brown et al.

Title Page 


\subsubsection{Carbonyl Chlorofluoride - COCIF}

COCIF is produced from the decomposition of molecules which contain single fluorine atoms, such as CFC-11. The first global observations of atmospheric COCIF from ACEFTS were made using data from between 2004 and 2007 (Fu et al., 2009). The ACE-

5 FTS retrieval of COCIF was used in both the stratospheric chlorine and fluorine budgets (Nassar et al., 2006a, b).

\subsubsection{Carbonyl Fluoride $-\mathrm{COF}_{2}$}

$\mathrm{COF}_{2}$ is produced from the decomposition of molecules which contain two fluorine atoms. Comparisons with measurements from Mk-IV show an agreement to within $10 \pm 20 \%$ (Velazco et al., 2011).

\subsubsection{Hydrogen Fluoride - HF}

$\mathrm{HF}$ is the main fluorine reservoir in the stratosphere. Retrievals of ACE-FTS HF have been compared to retrievals from the HALOE instrument. The results of a first analysis showed that the VMR of retrievals from ACE were around 10-20\% larger than HALOE

15 (McHugh et al., 2005; Mahieu et al., 2008). ACE-FTS retrievals were again compared once more to HALOE, these results showed that ACE-FTS retrievals were larger by between 5-20\% (Mahieu et al., 2008). HF from ACE-FTS has also been compared to measurements from FIRS-2. These results showed significant differences between ACE and FIRS-2 with differences between $60 \%$ (below $16 \mathrm{~km}$ where the VMR of HF is at its lowest) to $20 \%$ (Mahieu et al., 2008). This study also compared Mk-IV and ground-based FTIR to ACE HF. These results showed a difference of $\pm 10 \%$ between ACE and MK-IV above $19 \mathrm{~km}$ and an average difference of $\pm 7.4 \%$ for the average partial column averages from ground-based FTIRs.

Global stratospheric

fluorine inventories for 2004-2009

A. T. Brown et al.

Title Page 


\section{SLIMCAT 3D chemical transport model}

We have supplemented ACE observations with output from the SLIMCAT off-line threedimensional (3-D) chemical transport model (CTM). SLIMCAT contains a detailed treatment of stratospheric chemistry including the major species in the $\mathrm{O}_{\mathrm{x}}, \mathrm{NO}_{\mathrm{y}}, \mathrm{HO}_{\mathrm{x}}, \mathrm{Cl}_{\mathrm{y}}$

5 and $\mathrm{Br}_{\mathrm{y}}$ chemical families (Chipperfield, 1999; Feng et al., 2007). The model uses winds from meteorological analyses to specify horizontal transport while vertical motion in the stratosphere is calculated from diagnosed heating rates. This approach gives a realistic stratospheric circulation (Chipperfield, 2006; Monge-Sanz et al., 2007).

For this study SLIMCAT was integrated from 1977 to the present day at a horizontal 10 resolution of $5.6^{\circ} \times 5.6^{\circ}$ and 32 levels from the surface to about $60 \mathrm{~km}$. The model uses a $\sigma-\theta$ vertical coordinate (Chipperfield, 2006) and was forced by European Centre for Medium Range Weather Forecasts (ECMWF) reanalyses (ERA-Interim from 1989 onwards). The volume mixing ratio of source gases at the surface level were specified using data files compiled for WMO (2007) (WMO/UNEP, 2007). These global mean 15 surface values define the long-term tropospheric source gas trends in the model. The model zonal mean monthly output was averaged to create annual means for 4 latitude bins $\left(70-30^{\circ} \mathrm{N}, 30-00^{\circ} \mathrm{N}, 00^{\circ} \mathrm{N}-30^{\circ} \mathrm{S}\right.$ and $\left.30-70^{\circ} \mathrm{S}\right)$ on a $1 \mathrm{~km}$ altitude grid.

\section{Fluorine chemistry}

There are two principal reaction paths for the breakdown of fluorine-containing species in the atmosphere. The reaction path for a particular compound is determined by the number of fluorine atoms in the molecule.

Global stratospheric fluorine inventories for 2004-2009

A. T. Brown et al.

Title Page 


\subsection{CFCs and HCFCs which contain two fluorine atoms ( $\mathrm{COF}_{2}$ formation)}

The source gas molecule will first be broken down into $\mathrm{CF}_{2} \mathrm{Cl}$ and will then follow the following path (Tressaud, 2006):

$\mathrm{CF}_{2} \mathrm{Cl}+\mathrm{O}_{2}+\mathrm{M} \rightarrow \mathrm{CF}_{2} \mathrm{ClO}_{2}+\mathrm{M}$

$\mathrm{CF}_{2} \mathrm{ClO}_{2}+\mathrm{NO} \rightarrow \mathrm{CF}_{2} \mathrm{ClO}+\mathrm{NO}_{2}$

$\mathrm{CF}_{2} \mathrm{ClO}+\mathrm{O}_{2} \rightarrow \mathrm{COF}_{2}+\mathrm{ClO}_{2}$

$10 \mathrm{COF}_{2}+\mathrm{hv} \rightarrow \mathrm{FCO}+\mathrm{F}$

Above around $30 \mathrm{~km}$ the concentration of $\mathrm{COF}_{2}$ decreases as photolysis becomes more effective. The primary source of $\mathrm{COF}_{2}$ in the atmosphere is the decomposition of HCFC-22 and CFC-12. Contributions from HFCs, whilst smaller, are significant ensuring that the concentration of stratospheric $\mathrm{COF}_{2}$ has been increasing since 2004 15 (Brown et al., 2011).

\subsection{CFCs which contain a single fluorine atom (COCIF formation)}

The source gas molecule will first be broken down into $\mathrm{CFCl}_{2}$ and will then follow the following path (Tressaud, 2006):

$\mathrm{CFCl}_{2}+\mathrm{O}_{2}+\mathrm{M} \rightarrow \mathrm{CFCl}_{2} \mathrm{O}_{2}+\mathrm{M}$

$$
\mathrm{CFCl}_{2} \mathrm{O}_{2}+\mathrm{NO} \rightarrow \mathrm{CFCl}_{2} \mathrm{O}+\mathrm{NO}_{2}
$$

$\mathrm{CFCl}_{2} \mathrm{O}+\mathrm{O}_{2} \rightarrow \mathrm{COCl}_{2} \mathrm{O}+\mathrm{O}_{2} \rightarrow \mathrm{COCIF}+\mathrm{ClO}_{2}$

Global stratospheric fluorine inventories for 2004-2009

A. T. Brown et al.

Title Page 
Carbonyl chlorofluoride (COCIF) is less stable than $\mathrm{COF}_{2}$ and can be photolyzed more easily. It is therefore present in far smaller concentrations and peaks at lower altitudes 5 than $\mathrm{COF}_{2}$. The primary source for atmospheric COCIF is CFC-11.

The production of FCO from the decomposition of $\mathrm{COCIF}$ and $\mathrm{COF}_{2}$ leads to the formation of fluorine atoms, along the following reaction path:

$\mathrm{FCO}+\mathrm{O}_{2} \rightarrow \mathrm{FC}(\mathrm{O}) \mathrm{O}_{2} \rightarrow \mathrm{FO}+\mathrm{CO}_{2}$

$10 \mathrm{FO}+\mathrm{O}\left({ }^{1} \mathrm{D}\right) \rightarrow \mathrm{F}+\mathrm{O}_{2}$

The fluorine produced in both series of reactions will react with methane $\left(\mathrm{CH}_{4}\right)$, water $\left(\mathrm{H}_{2} \mathrm{O}\right)$ or molecular hydrogen $\left(\mathrm{H}_{2}\right)$ to form HF.

$\mathrm{F}+\mathrm{CH}_{4} \rightarrow \mathrm{HF}+\mathrm{CH}_{3}$

$15 \mathrm{~F}+\mathrm{H}_{2} \mathrm{O} \rightarrow \mathrm{HF}+\mathrm{OH}$

$\mathrm{F}+\mathrm{H}_{2} \rightarrow \mathrm{HF}+\mathrm{H}$

Photolysis of HF does not readily occur in the stratosphere, making HF an almost permanent reservoir of stratospheric fluorine (Tressaud, 2006). This means that the atmospheric concentrations of $\mathrm{F}$ and $\mathrm{FO}$ are very small, preventing fluorine from causing significant ozone loss. HF is ultimately removed from the stratosphere by slow transport to, and rainout in, the troposphere or by upward transport to the mesosphere where its mixing ratio remains constant up to high altitudes.

Global stratospheric fluorine inventories for 2004-2009

A. T. Brown et al.

Title Page 


\section{Fluorine budget method}

In total 16186 ACE-FTS occultations were used in this study. For this analysis the globe was divided into 4 latitude bands $\left(70-30^{\circ} \mathrm{N}, 30-0^{\circ} \mathrm{N}, 0^{\circ} \mathrm{N}-30^{\circ} \mathrm{S}\right.$ and $\left.30-70^{\circ} \mathrm{S}\right)$ chosen to represent the different transport regimes in the stratosphere. Outside of the

5 tropics and the polar regions the stratosphere is well mixed by breaking planetary scale waves. Within the tropics powerful convective transport can penetrate the tropopause, mixing the lower layers of the stratosphere. Occultations were divided by latitude and year; the number of data in each band is shown in Table 3. Data in each band were filtered using the median absolute distribution (MAD) of the data. The MAD is a robust stic which allows the variability of a data set to be calculated without giving large significance to outliers. For this reason it is ideal for filtering profiles retrieved from ACE which may contain a small number of large outliers due to problems with retrievals (such as problems with retrievals in occultations with high lying clouds or aerosols). Any value which was greater than 2.5 times the MAD from the median of the raw data depending on the distribution of the data around the median, of the ACE-FTS data ensuring that only outliers were removed. Once the outliers had been removed a mean profile of each species was produced by calculating the mean mixing ratio at each altitude. The error on this profile is calculated using the standard deviation of the data used to calculate each mean mixing ratio. This produces a profile with errors which vary with altitude, dependent on the variation of the data at each altitude. Profiles were extended by using the SLIMCAT profiles of the corresponding species scaled to match the ACE-FTS data at its highest and lowest retrieved altitude point. $\mathrm{SF}_{6}$ and $\mathrm{CF}_{4}$ did not have corresponding SLIMCAT data and so were extended vertically upwards at a constant VMR from the final retrieved altitude. All profiles were extended up to $54.5 \mathrm{~km}$ corresponding to the maximum altitude to which HF is retrieved by ACE-FTS.

The total fluorine volume mixing ratio was calculated at 54 levels between $0.5 \mathrm{~km}$ and $53.5 \mathrm{~km}$ corresponding to the ACE retrieval altitude grid. The equations used for
Global stratospheric fluorine inventories for 2004-2009

A. T. Brown et al.

Title Page 
this calculation are given below, where square brackets indicate volume mixing ratio (VMR). Following the convention of previous fluorine budgets (Nassar et al., 2006b; Zander et al., 1992), the total fluorine volume mixing ratio can be expressed as the sum of the total inorganic fluorine and the total organic fluorine. The terms inorganic and 5 organic are not used in the conventional sense in this work (and the fluorine budgets previous to this one). Instead the term organic fluorine can be loosely interpreted as those fluorine species which are emitted from the surface. Inorganic fluorine species are fluorine-containing molecules which are produced from the decomposition of the organic fluorine species (with the exception of $\mathrm{SF}_{6}$ ).

$10 \quad[$ Total Fluorine $]=[$ Total Inorganic Fluorine $]+[$ Total Organic Fluorine $]$

$[$ Total Inorganic Fluorine $]=[\mathrm{HF}]+2\left[\mathrm{COF}_{2}\right]+[\mathrm{COCIF}]+6\left[\mathrm{SF}_{6}\right]$

[Total Organic Fluorine $]=4\left[\mathrm{CF}_{4}\right]+2[\mathrm{CFC}-12]+[\mathrm{CFC}-11]+2[\mathrm{HCFC}-22]$

$$
\begin{aligned}
& +3[\text { CFC }-113]+4[\text { CFC-114] }+5[\text { CFC-115] }+2[\text { HCFC-142b }]+[\text { HCFC-141b }] \\
& +3[\mathrm{HFC}-23]+4[\mathrm{HFC}-134 \mathrm{a}]+2[\mathrm{HFC}-152 \mathrm{a}]+2[\mathrm{H}-1211]+3[\mathrm{H}-1301]
\end{aligned}
$$

\section{Results and discussion}

20 This section is divided into 5 subsections. Section 7.1 presents the vertical profiles of the total fluorine calculations, with a focus on the gradient on the profile and its implications for the total fluorine VMR in the atmosphere. Subsequently the slopes of the correlation plots between source fluorine species and reservoir fluorine species are presented and discussed in Sect. 7.2. The impacts of the individual species included in the total fluorine calculations on the total fluorine VMR are presented in Sect. 7.3. The final two sections present the changes in total fluorine between 2004 and 2009. Section 7.4 presents the changes in total stratospheric fluorine while Sect. 7.5 discusses the implications of these changes on climate forcing using a weighted total fluorine

Global stratospheric fluorine inventories for 2004-2009

A. T. Brown et al.

Title Page

Abstract

Introduction

Conclusions

Tables

References

Figures

14

- I

4

Back

$>$

Close

Full Screen / Esc

Printer-friendly Version

Interactive Discussion 
budget. These values were calculated using the mean total fluorine VMR weighted by the relative molecular mass, pressure and $20 \mathrm{yr}$ GWP.

\subsection{Vertical profiles}

$13,16885-16924,2013$

The results of the total fluorine calculations are shown in Figs. 1 and 2. As described

5 in Sect. 6 each point on the mean vertical profile of a species retrieved by ACE has an error, which represents the standard deviation of the data at that altitude, attached to it. The error bars shown on the plots represent the linear combination of the standard deviations of the contributing species for that particular altitude. The SLIMCAT profiles have been given a $5 \%$ error on their VMR. This value was chosen as it is an overesti10 mation of the error on the surface measurements used to force SLIMCAT, and allows for some error in model transport. The total fluorine profiles seem to follow a straight line with the majority of the deviations from this line coming from the HF retrieval. The mean total stratospheric fluorine and the slope of the total fluorine profile can be seen in Table 4. There does not appear to be any statistically significant difference between extra-tropical and tropical total fluorine VMR. The mean stratospheric fluorine in the extra-tropical region is generally larger than in the tropics. The differences between corresponding tropical and extra-tropical stratospheric means are generally smaller than the error on the values. This suggests that these differences are likely due to fluctuations in the retrieval of HF (the main source of atmospheric fluorine at higher altitudes) 20 as opposed to a true feature. The slopes of the total fluorine profiles are smaller in the tropical stratosphere than in the extra-tropical stratosphere. Since the age-of-air increases with altitude, the slope of the total fluorine profile represents the changes in the emissions of fluorine-containing species over time. The negative slopes of the total fluorine profiles show that the mixing ratios of fluorine-containing species have been increasing. Additionally, the slopes suggest that the rate of increase is faster in the tropics than in the extra-tropics. Figure 3 shows the mean percentage contribution of ACE-FTS and SLIMCAT VMR to the total fluorine profile for all years in the extra-tropical northern latitudes. The error bars represent the largest and smallest percentage contributions.

Global stratospheric fluorine inventories for 2004-2009

A. T. Brown et al.

Title Page

Abstract

Introduction

Conclusions

References

Tables

Figures

14

- I

4

Back

Close
Printer-friendly Version

Interactive Discussion

Full Screen / Esc Discussion 
All latitude bands show very similar altitude dependent percentage contributions. ACEFTS data accounts for between around $77 \%$ of the total fluorine, in the lower altitudes, to around $96 \%$ at the highest altitudes.

\subsection{Fluorine source and reservoir species correlations}

5 The fluorine-containing species used in this analysis can be divided into source and reservoir species, reservoir species being produced from the decomposition of source species. In this work HF, $\mathrm{COF}_{2}$ and COCIF are considered to be reservoir species; all other species $\left(\mathrm{CF}_{4}\right.$, CFC-12, CFC-11, HCFC-22, SF 6 , CFC-113, CFC-114, CFC-115, $\mathrm{H}-1211, \mathrm{H}-1301, \mathrm{HCFC}-141 \mathrm{~b}, \mathrm{HCFC}-142 \mathrm{~b}, \mathrm{HFC}-23, \mathrm{HFC}-134 \mathrm{a}$ and HFC-152a) are

10 source species. Correlating the source and reservoir species gives an indication as to whether the major fluorine-containing species have been considered; a slope close to one would show that most of the major fluorine containing species were included in the budget. It should be noted that this method cannot be used to check if all very long lived fluorine species (such as $\mathrm{SF}_{6}$ ) have been included in the study. Instead this method is a test whether the major source species which decompose in the stratosphere and reservoir species have been included in the budget. The results of these plots can be seen in Table 5. All calculated slopes are greater than 0.9 with the lowest values occurring in the tropical regions. The mean of the slope in the extra-tropics is $-0.97 \pm 0.01$ in the Northern Hemisphere and $-0.98 \pm 0.01$ Southern Hemisphere. In the northern tropics the mean slope of the correlation is $-0.91 \pm 0.02$, and in the southern tropics the mean slope is $-0.90 \pm 0.01$. These values suggest that the most important fluorine-containing species have indeed been included in this budget. Whilst many short-lived species are not included their overall contribution to stratospheric fluorine is small, and so their addition to the budget calculations would not significantly affect the final fluorine budget. The slopes from the tropical latitudes are smaller than those from extra-tropical latitudes. This is likely an artefact from the smaller number of occultations which are available at tropical latitudes.

Global stratospheric fluorine inventories for 2004-2009

A. T. Brown et al.

Title Page

Abstract

Introduction

Conclusions

Tables

References

Figures

14

$\rightarrow 1$

4

Back

Close 


\subsection{The contributions of species to the total fluorine budget}

The contributions of individual species to the total fluorine budget were calculated by producing a mean fluorine budget for each latitude band from annual data. Once these budgets had been produced the impact of each species on the fluorine budget could 5 be calculated. The contribution of individual species to the total fluorine budgets can be found in the appendix. The species which contribute the largest VMR to the total fluorine budget $\left(F_{\text {tot }}\right)$ for different altitudes and latitude bands are shown in Table 6. At the lower altitudes of this study, between 11 and $20 \mathrm{~km}$ in the extra-tropics (ET) and 11 and $29 \mathrm{~km}$ in the tropics $(\mathrm{T})$, the total fluorine VMR is dominated by CFC-12. At its 10 peak CFC-12 accounts for almost $40 \%$ of atmospheric fluorine. This occurs despite a decrease in the VMR of atmospheric CFC-12 during this time. At altitudes of up to $34 \mathrm{~km}$ in the tropics $(29 \mathrm{~km}$ in ET), the VMR of total fluorine from CFCs and halons is larger than that from HFCs and HCFCs. The contribution of HCFCs and HFCs to atmospheric fluorine is dominated by HCFC-22 which, at its peak at $10.5 \mathrm{~km}$, accounts 15 for between $14 \%$ and $15 \%$ of the total atmospheric fluorine depending on the latitude band. The combined contribution of the HCFCs (excluding HCFC-22) and HFCs used in this study peaks between $9.8 \%(\mathrm{ET})$ and $10.1 \%(\mathrm{~T})$. These values are significantly smaller than the combined contribution of the CFCs and halons (excluding CFC-12) which peak between $22 \%(E T)$ and $23 \%(T)$. Above $20 \mathrm{~km}$ in the ET and $29 \mathrm{~km}$ in the $20 \mathrm{~T}$, HF dominates reaching between $74 \%(\mathrm{ET})$ and $77 \%(\mathrm{~T})$ of total fluorine at $53.5 \mathrm{~km}$.

\subsection{Trends in stratospheric fluorine}

Since the fluorine budget has been calculated for the years between 2004 and 2009 it is possible to calculate trends in the annual changes of the mean total stratospheric fluorine. Figure 4 shows the trend plots for each of the 4 latitude bands and the reerror of a linear least squares fit to the data. Systematic errors are not considered in this work as they have not been calculated for ACE-FTS at this time. Systematic

\section{ACPD}

13, 16885-16924, 2013

Global stratospheric

fluorine inventories for 2004-2009

A. T. Brown et al.

Title Page

Abstract 
errors should not have a significant effect on the trends as they are consistent annually for each species used in this budget. In addition, altitude dependent systematic errors will be identical annually, thus as long as the same altitudes are used to calculate an average they will cancel for the annual trends. The VMR of total stratospheric

5 fluorine is increasing at a similar rate at all latitudes. The VMR of total stratospheric fluorine is increasing at a rate of $1.12 \pm 0.11 \% \mathrm{yr}^{-1}$ in the northern extra-tropical stratosphere, and $0.96 \pm 0.12 \% \mathrm{yr}^{-1}$ in the southern extra-tropical stratosphere. The rate of increase in stratospheric fluorine is also similar in the northern tropical stratosphere $\left(1.31 \pm 0.20 \% \mathrm{yr}^{-1}\right)$, and in the southern tropical $\left(1.21 \pm 0.22 \% \mathrm{yr}^{-1}\right)$. Northern and 10 southern hemispheric trends were calculated using the averages of the fluorine budgets of the relevant latitude bands. This method was preferred to calculating a budget from all the individual occultations within each hemisphere so that the budget is more representative of the whole hemisphere. As can be seen from Table 3 there are significantly more measurements at higher latitudes than in the tropics. A budget calculated from all the occultations in a particular hemisphere would therefore produce an average budget which was biased towards the higher latitudes. Total fluorine in the Northern Hemisphere and Southern Hemisphere is increasing at a similar rate, $1.21 \pm 0.14 \% \mathrm{yr}^{-1}$ in the Northern Hemisphere, and $1.07 \pm 0.21 \% \mathrm{yr}^{-1}$ in the Southern Hemisphere. Once more the errors quoted here are the statistical 1- $\sigma$ fitting error of a linear least squared fit to the data. Globally the VMR of fluorine in the stratosphere is increasing at a rate of $1.14 \pm 0.06 \% \mathrm{yr}^{-1}$. Despite the lower altitudes of the budget being dominated by CFC-12, a strong increase in the VMR of total fluorine is still seen. This is due to increases in the VMR of HCFCs and HFCs being significantly larger than the decreases in CFCs and halons during this time.

\subsection{Global Warming Potential weighted fluorine budget trends}

The main environmental impact of the increased atmospheric fluorine will be on warming in the troposphere and lower stratosphere region. The different species analysed for this work have different Global Warming Potentials (GWPs) (see Table 1) and therefore 16901

\section{ACPD}

13, 16885-16924, 2013

Global stratospheric

fluorine inventories for 2004-2009

A. T. Brown et al.

Title Page

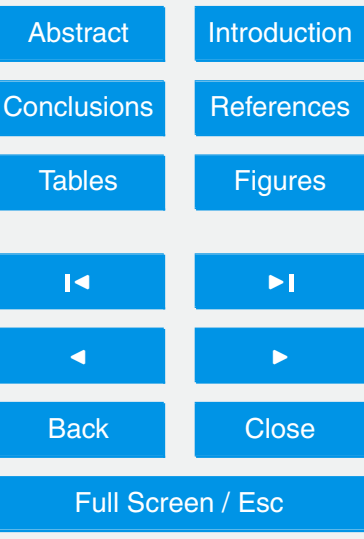

Printer-friendly Version

Interactive Discussion 
have different effects on climate. A more useful quantity is therefore the trend in the atmospheric fluorine-weighted GWP. Since the GWP is a measure of the global warming potential of $1 \mathrm{~kg}$ of substance compared to $1 \mathrm{~kg}$ of $\mathrm{CO}_{2}$, the GWP total fluorine cannot be calculated by simply weighting the VMR of the fluorine source species by their 5 GWP. Instead, the total fluorine must be weighted by the mass of the species and the GWP. The method used in this work to calculate this value was to weight each source species by its GWP and relative molecular mass. The VMR of these species was also weighted by the pressure, which is a measure of the atmospheric mass, at the corresponding altitude. Since the effect of these species is concentrated in the troposphere, 10 data above the tropopause was not included in the calculations of the GWP-weighted total fluorine. The time-series of these means can be seen in Fig. 5. GWP-weighted fluorine appears to be stable in all regions. Similar statistically insignificant increases are seen in both hemispheres with increases of $0.10 \pm 0.10 \%$ per year in the Northern Hemisphere tropics, and $0.11 \pm 0.13 \%$ per year in the Southern Hemisphere tropics.

Once more the error on these values was calculated using a 1- $\sigma$ fitting error of a linear least squares fit to the data. Extra-tropical latitudes also show statistically insignificant trends. In the Northern Hemisphere extra-tropical region the GWP-weighted fluorine appears to be decreasing at a rate of $-0.06 \pm 0.09 \%$ per year. Whilst in the Southern Hemisphere hemisphere extra-tropical region GWP-weighted fluorine is increasing at a rate of $0.02 \pm 0.03 \%$ per year. The errors on all of these GWP-weighted trends are larger than the reported GWP-weighted trends; these results suggest that it is likely that the GWP-weighted fluorine has remained roughly constant during this time. These trends are significantly smaller than the trends in the total fluorine presented in Sect. 7.4. The reason for this difference is the importance of CFCs and halons in these calculations. As can be seen in Table 1 if the species used in this study are ranked by GWP only 2 out of the largest 7 are not CFCs or halons. Since use of these species is prohibited under the Montreal Protocol the VMR of these species has been decreasing during the time frame of this study (Brown et al., 2011). HCFCs and, increasingly, HFCs have been replacing the species banned under the Montreal Protocol. The de-

\section{ACPD}

13, 16885-16924, 2013

Global stratospheric fluorine inventories for 2004-2009

A. T. Brown et al.

Title Page

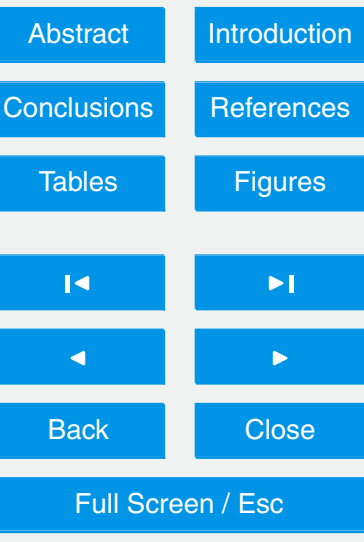

Printer-friendly Version

Interactive Discussion 
crease in CFCs and halons has, in effect, suppressed the GWP-weighted fluorine trend which would otherwise have risen during this time. Carrying out the same calculations without including CFCs and halons shows the effects of this suppression. The trends in the weighted total fluorine range between $3.51 \pm 0.16 \%$ and $3.92 \pm 0.19 \%$ per year 5 when CFCs and halons are not included (see Table 8). These results suggest that the Montreal Protocol has had a positive effect on reducing global warming. By banning the use of a number of ozone-depleting substances which were also potent greenhouse gases the Montreal Protocol has inadvertently slowed the rate of increase in the VMR of greenhouse gases in the atmosphere. This agrees with the work of Velders 10 et al. (2007), which stated that the Montreal Protocol had had a significant effect in reducing the emission of greenhouse gases.

\section{Conclusions}

This paper presents the stratospheric fluorine budget calculated for the years 2004 to 2009 for a number of latitude bands representing the extra-tropical and tropical 15 latitudes. The fluorine budgets were calculated using species retrieved by ACE-FTS. ACE-FTS measurements were supplemented with data from the SLIMCAT 3D chemical transport model. The fluorine budgets, therefore, include all the major fluorinecontaining species currently in the atmosphere. In the lower altitudes these budgets are dominated by the large mixing ratio of CFC-12. At its peak CFC-12 contributes around $39 \%$ of total fluorine. Other species are much less important. HCFC-22 contributes $15 \%$ at its maximum and combined contribution of the other HCFCs and HFCs used in this study peaks around $10 \%$. The remaining CFCs and halons used in this study contribute a maximum of about $23 \%$. As altitude increases HF overtakes CFC12 , between $21 \mathrm{~km}$ in the extra-tropics and $28 \mathrm{~km}$ in the tropics as the most dominant species in the total fluorine budget.

The gradients of the total fluorine profiles offer an indication of the long-term changes in total fluorine. All budgets exhibit a negative slope with altitude. Since air at higher

\section{ACPD}

13, 16885-16924, 2013

Global stratospheric fluorine inventories for 2004-2009

A. T. Brown et al.

Title Page

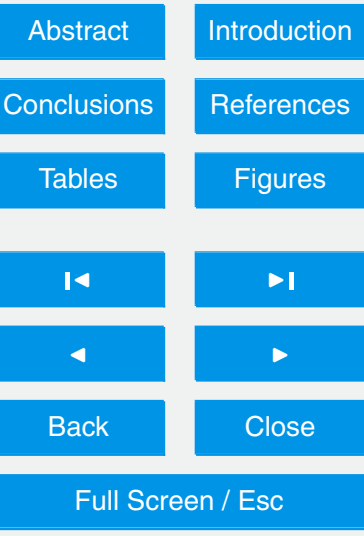

Printer-friendly Version

Interactive Discussion 
altitudes in the stratosphere is older than air at lower altitudes, higher concentrations observed at lower altitudes suggest that fluorine emissions have been increasing with time. Stratospheric fluorine is increasing in all the latitude bands used in this study.

Total tropospheric fluorine trends have been produced which have been weighted 5 by the GWPs of the individual species used in this study. These results allow the climatological implication of the increase in fluorine during this time to be quantified. Analysis carried out without using data for the CFCs or halons show GWP-weighted fluorine increasing by a mean of $3.85 \pm 0.07 \%$ per year in the Northern Hemisphere and $3.58 \pm 0.07 \%$ per year in the Southern Hemisphere. When CFCs and halons are included in the calculations it appears that the VMR of GWP-weighted fluorine has not changed significantly during this time. It appears that the decrease in species banned under the Montreal Protocol has limited the climatological effects of a general increase in the VMR of fluorine-containing species, in particular HCFCs and HFCs, during this time.

The mean contribution of individual species to the total fluorine VMR in the different latitude bands.

Acknowledgements. The ACE mission is supported primarily by the Canadian Space Agency. The research described here is supported by the UK Natural Environment Research Council (NERC) and the National Centre for Earth Observation (NCEO). The SLIMCAT modelling work was supported by the EU GeoMON project and NCAS.

\section{References}

Bernath, P. F., McElroy, C. T., Abrams, M. C., Boone, C. D., Butler, M., Camy-Peyret, C., Carleer, M., Clerbaux, C., Coheur, P. F., Colin, R., DeCola, P., DeMazière, M., Drummond, J. R., Dufour, D., Evans, W. F. J., Fast, H., Fussen, D., Gilbert, K., Jennings, D. E., Llewellyn, E. J., Lowe, R. P., Mahieu, E., McConnell, J. C., McHugh, M., McLeod, S. D., Michaud, R., Midwinter, C., Nassar, R., Nichitiu, F., Nowlan, C., Rinsland, C. P., Rochon, Y. J., Rowlands, N., Semeniuk, K., Simon, P., Skelton, R., Sloan, J. J., Soucy, M. A., Strong, K., Tremblay, P., Turnbull, D., Walker, K. A., Walkty, I., Wardle, D. A., Wehrle, V., Zander, R., and Zou,

Global stratospheric fluorine inventories for 2004-2009

A. T. Brown et al.

Title Page

Abstract

Introduction

Conclusions

References

Tables

Figures

14

DI

4

Back

Close

Full Screen / Esc

Printer-friendly Version

Interactive Discussion 
J.: Atmospheric Chemistry Experiment (ACE): Mission overview, Geophys. Res. Lett., 32, L15S01, doi:10.1029/2005gl022386, 2005.

Bernath, P. F.: Atmospheric chemistry experiment (ACE): Analytical chemistry from orbit, TrAC Trends in Analytical Chemistry, 25, 647-654, doi:10.1016/j.trac.2006.05.001, 2006.

5 Boone, C. D., Nassar, R., Walker, K. A., Rochon, Y., McLeod, S. D., Rinsland, C. P., and Bernath, P. F.: Retrievals for the atmospheric chemistry experiment Fourier-transform spectrometer, Appl. Opt., 44, 7218-7231, 2005.

Brown, A. T., Chipperfield, M. P., Boone, C., Wilson, C., Walker, K. A., and Bernath, P. F.: Trends in atmospheric halogen containing gases since 2004, J. Quant. Spectrosc. Ra. Transfer, 112, 2552-2566, doi:10.1016/j.jqsrt.2011.07.005, 2011.

Chipperfield, M. P.: Multiannual simulations with a three-dimensional chemical transport model, J. Geophys. Res., 104, 1781-1805, doi:10.1029/98jd02597, 1999.

Chipperfield, M. P.: New Version of the TOMCAT/SLIMCAT Off-Line Chemical Transport Model: Intercomparison of Stratospheric Tracer Experiments, Q. J. Roy. Meteorol. Soc., 132, 1179$15 \quad$ 1203, 2006.

Feng, W., Chipperfield, M. P., Dorf, M., Pfeilsticker, K., and Ricaud, P.: Mid-latitude ozone changes: studies with a 3-D CTM forced by ERA-40 analyses, Atmos. Chem. Phys., 7, 23572369, doi:10.5194/acp-7-2357-2007, 2007.

Fu, D., Boone, C. D., Bernath, P. F., Weisenstein, D. K., Rinsland, C. P., Manney, G. L., and Walker, K. A.: First global observations of atmospheric COCIF from the Atmospheric Chemistry Experiment mission, J. Quant. Spectrosc. Ra. Transfer, 110, 974-985, doi:10.1016/j.jqsrt.2009.02.018, 2009.

Harrison, J. J., Boone, C. D., Brown, A. T., Allen, N. D. C., Toon, G. C., and Bernath, P. F.: First remote sensing observations of trifluoromethane (HFC-23) in the upper troposphere and lower stratosphere, J. Geophys. Res., 117, D05308, doi:10.1029/2011jd016423, 2012.

Lide, D.: Handbook of Chemistry and Physics, in, Chemical Rubber Publishing Company, USA, 9-109, 1990.

Mahieu, E., Duchatelet, P., Demoulin, P., Walker, K. A., Dupuy, E., Froidevaux, L., Randall, C., Catoire, V., Strong, K., Boone, C. D., Bernath, P. F., Blavier, J.-F., Blumenstock, T., Coffey, M., so De Mazière, M., Griffith, D., Hannigan, J., Hase, F., Jones, N., Jucks, K. W., Kagawa, A., Kasai, Y., Mebarki, Y., Mikuteit, S., Nassar, R., Notholt, J., Rinsland, C. P., Robert, C., Schrems, O., Senten, C., Smale, D., Taylor, J., Tétard, C., Toon, G. C., Warneke, T., Wood, S. W., Zander, R., and Servais, C.: Validation of ACE-FTS v2.2 measurements of $\mathrm{HCl}, \mathrm{HF}, \mathrm{CCl} 3 \mathrm{~F}$ and

13, 16885-16924, 2013

Global stratospheric

fluorine inventories for 2004-2009

A. T. Brown et al.

Title Page

Abstract

Introduction

Conclusions

References

Tables

Figures

14

- I

4

Back

$>$

Close

Full Screen / Esc

Printer-friendly Version

Interactive Discussion 
CCl2F2 using space-, balloon- and ground-based instrument observations, Atmos. Chem. Phys., 8, 6199-6221, doi:10.5194/acp-8-6199-2008, 2008.

McHugh, M., Magill, B., Walker, K. A., Boone, C. D., Bernath, P. F., and Russell III, J. M.,: Comparison of atmospheric retrievals from ACE and HALOE, Geophys. Res. Lett., 32, L15S10, 5 doi:10.1029/2005gl022403, 2005.

Mikuteit, S.: Trendbestimmung stratosphärischer Spurengase mit Hilfebodengebundener FTIRMessungen - dissertation, FZK Report No. 7385, GERMANY, 2008.

Monge-Sanz, B. M., Chipperfield, M. P., Simmons, A. J., and Uppala, S. M.: Mean age of air and transport in a CTM: Comparison of different ECMWF analyses, Geophys. Res. Lett., 34,

$10 \quad$ L04801, doi:10.1029/2006gl028515, 2007.

Nassar, R., Bernath, P. F., Boone, C. D., Clerbaux, C., Coheur, P. F., Dufour, G., Froidevaux, L., Mahieu, E., McConnell, J. C., McLeod, S. D., Murtagh, D. P., Rinsland, C. P., Semeniuk, K., Skelton, R., Walker, K. A., and Zander, R.: A global inventory of stratospheric chlorine in 2004, J. Geophys. Res., 111, D22312, doi:10.1029/2006jd007073, 2006a.

Nassar, R., Bernath, P. F., Boone, C. D., McLeod, S. D., Skelton, R., Walker, K. A., Rinsland, C. P., and Duchatelet, P.: A global inventory of stratospheric fluorine in 2004 based on Atmospheric Chemistry Experiment Fourier transform spectrometer (ACE-FTS) measurements, J. Geophys. Res., 111, D22313, doi:10.1029/2006jd007395, 2006b.

Sen, B., Toon, G. C., Blavier, J. F., Fleming, E. L., and Jackman, C. H.: Balloon-borne observations of midlatitude fluorine abundance, J. Geophys. Res., 101, 9045-9054, doi:10.1029/96jd00227, 1996.

Solomon, S., Qin, D., Manning, M., Alley, R. B., Berntsen, T.,Bindoff, N. L., Chen, Z., Chidthaisong, A., Gregory, J. M., Hegerl, G. C., Heimann, M., Hewitson, B., Hoskins, B. J., Joos, F., Jouzel, J., Kattsov, V., Lohmann, U., Matsuno, T., Molina, M., Nicholls, N., Overpeck, J., Raga, G., Ramaswamy, V., Ren, J., Rusticucci, M., Somerville, R., Stocker, T. F., Whetton, P., Wood, R. A., and Wratt, D: Climate Change 2007: The Physical Science Basis. Contribution of Working Group I to the Fourth Assessment Report of the Intergovernmental Panel on Climate Change, Cambridge University Press, Cambridge, 2007.

Tressaud, A.: Fluorine and the Environment: Atmospheric Chemistry, Emissions, \& Lithosphere, Elsevier, 2006.

UNEP: Handbook for the Montreal Protocol on Substances that Deplete the Ozone Layer 8ed., Secretariat for The Vienna Convention for the Protection of the Ozone Layer \& The Montreal Protocol on Substances that Deplete the Ozone Layer, Kenya, 2009.

\section{ACPD}

13, 16885-16924, 2013

Global stratospheric

fluorine inventories for 2004-2009

A. T. Brown et al.

\section{Title Page}

\section{Abstract}

Introduction

Conclusions

References

Tables

Figures

14

$\rightarrow 1$

4

Back

Close

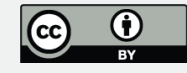


Velazco, V. A., Toon, G. C., Blavier, J.-F. L., Kleinböhl, A., Manney, G. L., Daffer, W. H., Bernath, P. F., Walker, K. A., and Boone, C.: Validation of the Atmospheric Chemistry Experiment by noncoincident MkIV balloon profiles, J. Geophys. Res., 116, D06306, doi:10.1029/2010jd014928, 2011.

5 WMO/UNEP: Scientific Assessment of Stratospheric Ozone, 2007.

Velders, G. J. M., Andersen, S. O., Daniel, J. S., Fahey, D. W., and McFarland, M.: The importance of the Montreal Protocol in protecting climate, Proceedings of the National Academy of Sciences, 104, 4814-4819, 10.1073/pnas.0610328104, 2007.Zander, R., Gunson, M. R., Farmer, C. B., Rinsland, C. P., Irion, F. W., and Mahieu, E.: The 1985 chlorine and fluorine inventories in the stratosphere based on ATMOS observations at $30^{\circ}$ north latitude, J. Atmos. Chem., 15, 171-186, doi:10.1007/bf00053758, 1992.

\section{ACPD}

13, 16885-16924, 2013

Global stratospheric fluorine inventories for 2004-2009

A. T. Brown et al.

\section{Title Page}

Abstract

Introduction

Conclusions

References

Tables

Figures

14

$\rightarrow 1$

4

Back

$>$

Close

Full Screen / Esc

Printer-friendly Version

Interactive Discussion 


\section{ACPD}

13, 16885-16924, 2013

Table 1. The global warming potential, on a $20 \mathrm{yr}$ timescale, of some of the species used in this work (Solomon, 2007).

\begin{tabular}{ll}
\hline Species & Global Warming Potential \\
\hline CF $_{4}$ & 5210 \\
CFC-11 $\left(\mathrm{CCl}_{3} \mathrm{~F}\right)$ & 6730 \\
CFC-12 $\left(\mathrm{CCl}_{2} \mathrm{~F}_{2}\right)$ & 11000 \\
CFC-113 $\left(\mathrm{C}_{2} \mathrm{Cl}_{3} \mathrm{~F}_{3}\right)$ & 6540 \\
CFC-114 $\left(\mathrm{C}_{2} \mathrm{Cl}_{2} \mathrm{~F}_{4}\right)$ & 8040 \\
CFC-115 $\left(\mathrm{C}_{2} \mathrm{ClF}_{5}\right)$ & 5310 \\
Halon-1301 $\left(\mathrm{CBrF}_{3}\right)$ & 8480 \\
Halon-1211 $\left(\mathrm{CBrClF}_{2}\right)$ & 4750 \\
HCFC-22 $\left(\mathrm{CHClF}_{2}\right)$ & 5160 \\
HCFC-141b $\left(\mathrm{C}_{2} \mathrm{H}_{3} \mathrm{Cl}_{2} \mathrm{~F}\right)$ & 2250 \\
HCFC-142b $\left(\mathrm{C}_{2} \mathrm{H}_{3} \mathrm{CIF}_{2}\right)$ & 5490 \\
HFC-23 $\left(\mathrm{CHF}_{3}\right)$ & 12000 \\
HFC-134a $\left(\mathrm{C}_{2} \mathrm{H}_{2} \mathrm{~F}_{4}\right)$ & 3830 \\
HFC-152a $\left(\mathrm{C}_{2} \mathrm{H}_{4} \mathrm{~F}_{2}\right)$ & 437 \\
SF & 16300 \\
\hline
\end{tabular}

Global stratospheric fluorine inventories for 2004-2009
A. T. Brown et al.

\section{Title Page}

Abstract

Introduction

Conclusions

References

Tables

Figures

14

$>1$

4

Back

$>$

Full Screen / Esc

Printer-friendly Version

Interactive Discussion 


\section{ACPD}

13, 16885-16924, 2013

Global stratospheric fluorine inventories

for 2004-2009

A. T. Brown et al.

\begin{tabular}{lll}
\hline \multirow{2}{*}{ Species } & \multicolumn{2}{c}{ Altitude $(\mathrm{km})$} \\
\cline { 2 - 3 } & Polar & Equatorial \\
\hline CFC-11 $\left(\mathrm{CCl}_{3} \mathrm{~F}\right)$ & $5-23$ & $6-28$ \\
CFC-12 $\left(\mathrm{CCl}_{2} \mathrm{~F}_{2}\right)$ & $5-28$ & $5-36$ \\
HCFC-22 $\left(\mathrm{CHF}_{2} \mathrm{Cl}\right)$ & $5-30$ & $7-30$ \\
COCIF & $13-25$ & $15-32$ \\
$\mathrm{COF}_{2}$ & $12-34$ & $12-45$ \\
SF $_{6}$ & $8-32$ & $12-32$ \\
$\mathrm{CF}_{4}$ & $15-55$ & $15-55$ \\
$\mathrm{HF}$ & $12-52$ & $12-57$ \\
\hline
\end{tabular}

Title Page

Abstract

Introduction

Conclusions

References

Tables

Figures

$1<$

DI

4

Back

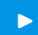

Close

Full Screen / Esc

Printer-friendly Version

Interactive Discussion 


\section{ACPD}

13, 16885-16924, 2013

Global stratospheric fluorine inventories

for 2004-2009

\section{A. T. Brown et al.}

\section{Title Page}

\begin{tabular}{llllll}
\hline Year & $70-30^{\circ} \mathrm{N}$ & $30-0^{\circ} \mathrm{N}$ & $0-30^{\circ} \mathrm{S}$ & $30-70^{\circ} \mathrm{S}$ & Total \\
\hline 2004 & 788 & 171 & 153 & 960 & 2072 \\
2005 & 1631 & 278 & 301 & 1592 & 3802 \\
2006 & 1166 & 164 & 178 & 1038 & 2546 \\
2007 & 887 & 116 & 129 & 804 & 1936 \\
2008 & 1449 & 134 & 197 & 1427 & 3207 \\
2009 & 1162 & 168 & 202 & 1091 & 2623 \\
\hline
\end{tabular}

\section{Abstract}

Conclusions

Tables

14

4

Back

Introduction

References

Figures

$>1$

$>$

Close

Full Screen / Esc

Printer-friendly Version

Interactive Discussion 
Table 4. The slopes of the total fluorine profile and the mean stratospheric volume mixing ratio of the fluorine budgets for different latitude bands.

\begin{tabular}{rrrrr}
\hline Year & \multicolumn{3}{c}{$70-30^{\circ} \mathrm{N}$} & \multicolumn{2}{c}{$30-0^{\circ} \mathrm{N}$} \\
\cline { 2 - 5 } & $\begin{array}{r}\text { Slope of total fluorine } \\
\text { profile [ppt km }{ }^{-1} \text { ] }\end{array}$ & $\begin{array}{r}\text { Mean Stratospheric } \\
\text { Fluorine [ppt] }\end{array}$ & $\begin{array}{r}\text { Slope of total fluorine } \\
\text { profile }\left[\mathrm{ppt} \mathrm{km}^{-1} \text { ] }\right.\end{array}$ & $\begin{array}{r}\text { Mean Stratospheric } \\
\text { Fluorine [ppt] }\end{array}$ \\
\hline 2004 & $-1.76 \pm 0.38$ & $2478 \pm 33$ & $-6.94 \pm 0.45$ & $2429 \pm 115$ \\
2005 & $-2.21 \pm 0.36$ & $2501 \pm 33$ & $-4.29 \pm 0.31$ & $2508 \pm 68$ \\
2006 & $-2.68 \pm 0.34$ & $2529 \pm 43$ & $-5.41 \pm 0.28$ & $2513 \pm 82$ \\
2007 & $-1.46 \pm 0.27$ & $2573 \pm 25$ & $-3.84 \pm 0.39$ & $2551 \pm 65$ \\
2008 & $-1.78 \pm 0.41$ & $2603 \pm 38$ & $-4.51 \pm 0.53$ & $2577 \pm 82$ \\
2009 & $-2.03 \pm 0.35$ & $2607 \pm 32$ & $-4.37 \pm 0.47$ & $2604 \pm 78$ \\
\hline Year & 0 & \multicolumn{3}{c}{$30^{\circ} \mathrm{S}-70^{\circ} \mathrm{S}$} \\
& $0^{\circ} \mathrm{N}-30^{\circ} \mathrm{S}$ & & \\
& Slope of total fluorine & Mean Stratospheric & Slope of total fluorine & Mean Stratospheric \\
profile [ppt km ${ }^{-1}$ ] & Fluorine [ppt] & profile [ppt km ${ }^{-1}$ ] & Fluorine [ppt] \\
\hline 2004 & $-4.54 \pm 0.39$ & $2455 \pm 62$ & $-1.28 \pm 0.22$ & $2494 \pm 24$ \\
2005 & $-5.17 \pm 0.62$ & $2451 \pm 89$ & $-1.42 \pm 0.23$ & $2510 \pm 25$ \\
2006 & $-6.23 \pm 0.51$ & $2488 \pm 76$ & $-0.95 \pm 0.38$ & $2521 \pm 33$ \\
2007 & $-5.49 \pm 0.46$ & $2508 \pm 71$ & $-0.29 \pm 0.39$ & $2559 \pm 38$ \\
2008 & $-5.90 \pm 0.40$ & $2569 \pm 69$ & $-1.42 \pm 0.38$ & $2569 \pm 31$ \\
2009 & $-4.53 \pm 0.42$ & $2592 \pm 64$ & $-1.21 \pm 0.26$ & $2621 \pm 28$ \\
\hline
\end{tabular}

Global stratospheric fluorine inventories for 2004-2009

A. T. Brown et al.

\section{Title Page}

Abstract

Introduction

Conclusions

References

Tables

Figures

14

$>1$

4

Back

Close 


\section{ACPD}

13, 16885-16924, 2013

Global stratospheric fluorine inventories for 2004-2009

A. T. Brown et al.

Table 5. The slopes of the correlation between fluorine source species $\left(\mathrm{CF}_{4}, \mathrm{CFC}-12, \mathrm{CFC}-\right.$ 11, HCFC-22, SF ${ }_{6}$, CFC-113, CFC-114, CFC-115, H-1211, H-1301, HCFC-141b, HCFC-142b, HFC-23, HFC-134a and HFC-152a) and fluorine reservoir species (HF, $\mathrm{COF}_{2}$ and $\mathrm{COCIF}$ ).

\begin{tabular}{lrrrr}
\hline Year & $70-30^{\circ} \mathrm{N}$ & $30-0^{\circ} \mathrm{N}$ & $0^{\circ} \mathrm{N}-30^{\circ} \mathrm{S}$ & $30-70^{\circ} \mathrm{S}$ \\
\hline 2004 & $-0.97 \pm 0.01$ & $-0.88 \pm 0.01$ & $-0.92 \pm 0.01$ & $-0.97 \pm 0.01$ \\
2005 & $-0.96 \pm 0.01$ & $-0.92 \pm 0.01$ & $-0.90 \pm 0.01$ & $-0.97 \pm 0.01$ \\
2006 & $-0.96 \pm 0.01$ & $-0.91 \pm 0.01$ & $-0.89 \pm 0.01$ & $-0.97 \pm 0.01$ \\
2007 & $-0.97 \pm 0.01$ & $-0.93 \pm 0.01$ & $-0.90 \pm 0.01$ & $-0.99 \pm 0.01$ \\
2008 & $-0.97 \pm 0.01$ & $-0.92 \pm 0.01$ & $-0.90 \pm 0.01$ & $-0.97 \pm 0.01$ \\
2009 & $-0.96 \pm 0.01$ & $-0.92 \pm 0.01$ & $-0.92 \pm 0.01$ & $-0.98 \pm 0.01$ \\
Mean & $-0.97 \pm 0.01$ & $-0.91 \pm 0.02$ & $-0.90 \pm 0.01$ & $-0.98 \pm 0.01$ \\
\hline
\end{tabular}

Title Page

\section{Full Screen / Esc}




\section{ACPD}

13, 16885-16924, 2013

Global stratospheric fluorine inventories

for 2004-2009

Table 6. The species and its mean percentage contribution which contribute the largest VMR to the total fluorine budget $\left(F_{\text {tot }}\right)$ for different altitudes and latitude bands.

\begin{tabular}{|c|c|c|c|c|c|}
\hline Species & Altitude Range & $\% F_{\text {tot }}$ range & Species & Altitude Range & $\% F_{\text {tot }}$ range \\
\hline \multicolumn{3}{|c|}{$70-30^{\circ} \mathrm{N}$} & \multicolumn{3}{|c|}{$30-0^{\circ} \mathrm{N}$} \\
\hline CFC-12 & $10.5-20.5 \mathrm{~km}$ & $38.9-25.8$ & CFC-12 & $10.5-28.5 \mathrm{~km}$ & $39.5-23.8$ \\
\hline HF & $21.5-53.5 \mathrm{~km}$ & $24.9-77.3$ & $\mathrm{HF}$ & $29.5-53.5 \mathrm{~km}$ & $22.2-74.5$ \\
\hline Species & Altitude Range & $\% F_{\text {tot }}$ range & Species & Altitude Range & $\% F_{\text {tot }}$ range \\
\hline \multicolumn{3}{|c|}{$0^{\circ} \mathrm{N}-30^{\circ} \mathrm{S}$} & \multicolumn{3}{|c|}{$30-70^{\circ} \mathrm{S}$} \\
\hline CFC & 10.5 & 39.3 & CFC-12 & 10.5 & $38.5-24.0$ \\
\hline $\mathrm{HF}$ & $28.5-53.5 \mathrm{~km}$ & $22.3-74.5$ & $\mathrm{HF}$ & $20.5-53.5 \mathrm{~km}$ & $26.3-76.6$ \\
\hline
\end{tabular}

A. T. Brown et al.

Title Page

Abstract

Introduction

Conclusions

Tables

References

Figures

14

DI

Back

Close

\section{Full Screen / Esc}

Printer-friendly Version

Interactive Discussion 
Global stratospheric fluorine inventories for 2004-2009

A. T. Brown et al.

Table 7. The trends in the mean stratospheric total fluorine volume mixing ratio between 2004 and 2009 for different latitude bands and the $\mathrm{NH}$ and $\mathrm{SH}$.

\begin{tabular}{lcc}
\hline & $\mathrm{pptyr}^{-1}$ & $\% \mathrm{yr}^{-1}$ \\
\hline $70-30^{\circ} \mathrm{N}$ & $28.3 \pm 2.7$ & $1.12 \pm 0.11$ \\
$30-0^{\circ} \mathrm{N}$ & $32.5 \pm 4.9$ & $1.31 \pm 0.20$ \\
$0^{\circ} \mathrm{N}-30^{\circ} \mathrm{S}$ & $29.8 \pm 5.3$ & $1.21 \pm 0.22$ \\
$30-70^{\circ} \mathrm{S}$ & $24.3 \pm 3.1$ & $0.96 \pm 0.12$ \\
Northern Hemisphere & $30.3 \pm 2.7$ & $1.21 \pm 0.11$ \\
Southern Hemisphere & $26.8 \pm 3.7$ & $1.07 \pm 0.15$ \\
\hline
\end{tabular}

Title Page

Abstract

Conclusions

Tables

14

4

Back

Introduction

References

\section{Figures}

-I

$>$

Close

Full Screen / Esc

Printer-friendly Version

Interactive Discussion 


\section{ACPD}

13, 16885-16924, 2013

Global stratospheric fluorine inventories

for 2004-2009

A. T. Brown et al.

Table 8. The global warming potential-weighted trends in the total fluorine volume mixing ratio between 2004 and 2009. The weighted total fluorine budgets were also calculated without including CFCs and halons so that the impact of the Montreal Protocol on global warming potential weighted fluorine could be quantified.

\begin{tabular}{lrr}
\hline Latitude band & $\begin{array}{r}\text { Weighted total } \\
\text { fluorine trend }\left(\% \mathrm{yr}^{-1}\right)\end{array}$ & $\begin{array}{r}\text { Weighted totalhalons } \\
\text { fluorine trend without } \\
\text { CFCs and included }\left(\% \mathrm{yr}^{-1}\right)\end{array}$ \\
\hline $70-30^{\circ} \mathrm{N}$ & $-0.06 \pm 0.09$ & $3.78 \pm 0.34$ \\
$30-0^{\circ} \mathrm{N}$ & $0.10 \pm 0.10$ & $3.92 \pm 0.19$ \\
$0^{\circ} \mathrm{N}-30^{\circ} \mathrm{S}$ & $0.11 \pm 0.13$ & $3.65 \pm 0.27$ \\
$30-70^{\circ} \mathrm{S}$ & $0.02 \pm 0.03$ & $3.51 \pm 0.16$ \\
\hline
\end{tabular}

Title Page

Abstract

Introduction

Conclusions

Tables

$1<$

4

Back

References

Figures

DI

$>$

Close

Full Screen / Esc

Printer-friendly Version

Interactive Discussion 


\section{ACPD}

13, 16885-16924, 2013

Table A1. The percentage contribution of each species to the total fluorine budget in the latitude bands between $70^{\circ} \mathrm{N}$ and $30^{\circ} \mathrm{N}$.

\begin{tabular}{|c|c|c|c|c|c|c|c|c|c|c|c|c|c|c|c|c|c|c|}
\hline Altitude & $\mathrm{HF}$ & $\mathrm{CF}_{4}$ & CFC-12 & CFC-11 & $\mathrm{COF}_{2}$ & COCIF & HCFC-22 & $\mathrm{SF}_{6}$ & CFC-113 & CFC-114 & CFC-115 & HCFC-142b & HCFC-141b & HFC-23 & HFC-134a & HFC-152a & $\mathrm{H}-1211$ & $\mathrm{H}-1301$ \\
\hline 10.5 & 1.2 & 11.3 & 38.9 & 8.9 & 0.7 & 0.2 & 14.4 & 1.3 & 8.5 & 2.5 & 1.7 & 1.2 & 0.7 & 2.1 & 5.4 & 0.3 & 0.3 & 0.4 \\
\hline 11.5 & 2.2 & 11.3 & 38.5 & 8.6 & 1.3 & 0.4 & 14.2 & 1.3 & 8.2 & 2.4 & 1.7 & 1.1 & 0.6 & 2.1 & 5.1 & 0.3 & 0.3 & 0.4 \\
\hline 12.5 & 3.1 & 11.4 & 38.1 & 8.3 & 1.8 & 0.5 & 14.1 & 1.3 & 7.9 & 2.4 & 1.7 & 1.1 & 0.6 & 2.1 & 4.9 & 0.3 & 0.2 & 0.4 \\
\hline 13.5 & 3.9 & 11.4 & 37.5 & 8.1 & 2.1 & 0.6 & 14.3 & 1.3 & 7.7 & 2.3 & 1.7 & 1.1 & 0.6 & 2.0 & 4.8 & 0.2 & 0.2 & 0.4 \\
\hline 14.5 & 4.9 & 11.4 & 36.9 & 7.8 & 2.4 & 0.6 & 14.3 & 1.3 & 7.4 & 2.3 & 1.7 & 1.0 & 0.6 & 2.0 & 4.6 & 0.2 & 0.2 & 0.3 \\
\hline 15.5 & 6.2 & 11.4 & 36.1 & 7.3 & 3.1 & 0.7 & 14.1 & 1.3 & 7.2 & 2.2 & 1.7 & 1.0 & 0.5 & 2.0 & 4.5 & 0.2 & 0.2 & 0.3 \\
\hline 16.5 & 8.3 & 11.5 & 34.9 & 6.6 & 4.1 & 0.9 & 13.4 & 1.3 & 6.8 & 2.2 & 1.6 & 1.0 & 0.5 & 2.0 & 4.3 & 0.2 & 0.2 & 0.3 \\
\hline 17.5 & 11.1 & 11.6 & 33.0 & 5.8 & 5.6 & 1.1 & 12.5 & 1.3 & 6.3 & 2.1 & 1.6 & 0.9 & 0.4 & 1.9 & 4.0 & 0.2 & 0.1 & 0.3 \\
\hline 18.5 & 14.5 & 11.7 & 30.8 & 4.8 & 7.3 & 1.4 & 11.8 & 1.3 & 5.6 & 2.0 & 1.6 & 0.9 & 0.4 & 1.9 & 3.6 & 0.2 & 0.1 & 0.2 \\
\hline 19.5 & 18.0 & 11.7 & 28.3 & 3.7 & 9.0 & 1.6 & 11.3 & 1.3 & 5.0 & 1.8 & 1.6 & 0.8 & 0.3 & 1.9 & 3.3 & 0.1 & 0.1 & 0.2 \\
\hline 20.5 & 21.6 & 11.8 & 25.8 & 2.6 & 10.6 & 1.7 & 10.7 & 1.2 & 4.4 & 1.7 & 1.5 & 0.8 & 0.3 & 1.8 & 3.1 & 0.1 & 0.0 & 0.2 \\
\hline $\begin{array}{l}21.5 \\
21.5\end{array}$ & $\begin{array}{l}2.0 \\
24.9\end{array}$ & 11.7 & $\begin{array}{l}25.8 \\
23.2\end{array}$ & $\begin{array}{l}2.0 \\
1.7\end{array}$ & $\begin{array}{l}1.6 \\
12.3\end{array}$ & $\begin{array}{l}1.7 \\
1.8\end{array}$ & 10.2 & $\begin{array}{l}1.2 \\
1.2\end{array}$ & $\begin{array}{l}3.4 \\
3.9\end{array}$ & $\begin{array}{l}1.1 \\
1.6\end{array}$ & $\begin{array}{l}1.5 \\
1.5\end{array}$ & $\begin{array}{l}0.8 \\
0.7\end{array}$ & $\begin{array}{l}0.3 \\
0.2\end{array}$ & $\begin{array}{l}1.8 \\
1.8\end{array}$ & $\begin{array}{l}3.1 \\
2.9\end{array}$ & 0.1 & 0.0 & 0.1 \\
\hline 22.5 & 27.9 & 11.7 & 20.7 & 1.1 & 13.7 & 1.7 & 9.8 & 1.2 & 3.4 & 1.5 & 1.5 & 0.7 & 0.2 & 1.8 & 2.8 & 0.1 & 0.0 & 0.1 \\
\hline 23.5 & 30.8 & 11.6 & 18.4 & 0.7 & 15.1 & 1.5 & 9.5 & 1.2 & 2.9 & 1.5 & 1.4 & 0.7 & 0.2 & 1.8 & 2.7 & 0.1 & 0.0 & 0.1 \\
\hline 24.5 & 33.6 & 11.6 & 16.0 & 0.4 & 16.3 & 1.3 & 9.1 & 1.2 & 2.4 & 1.4 & 1.4 & 0.6 & 0.1 & 1.7 & 2.6 & 0.1 & 0.0 & 0.1 \\
\hline 25.5 & 36.6 & 11.5 & 13.7 & 0.2 & 17.2 & 1.0 & 8.8 & 1.2 & 2.0 & 1.3 & 1.4 & 0.6 & 0.1 & 1.7 & 2.5 & 0.1 & 0.0 & 0.0 \\
\hline 26.5 & 39.6 & 11.5 & 11.4 & 0.1 & 18.0 & 0.8 & 8.4 & 1.2 & 1.6 & 1.2 & 1.4 & 0.6 & 0.1 & 1.7 & 2.4 & 0.1 & 0.0 & 0.0 \\
\hline 27.5 & 42.8 & 11.5 & 9.2 & 0.1 & 18.4 & 0.6 & 8.0 & 1.2 & 1.2 & 1.1 & 1.3 & 0.5 & 0.1 & 1.7 & 2.3 & 0.0 & 0.0 & 0.0 \\
\hline 28.5 & 45.9 & 11.4 & 7.2 & 0.0 & 18.5 & 0.4 & 7.7 & 1.2 & 0.9 & 1.0 & 1.3 & 0.5 & 0.0 & 1.7 & 2.2 & 0.0 & 0.0 & 0.0 \\
\hline 29.5 & 49.0 & 11.4 & 5.7 & 0.0 & 18.1 & 0.3 & 7.3 & 1.2 & 0.7 & 0.9 & 1.3 & 0.4 & 0.0 & 1.6 & 2.1 & 0.0 & 0.0 & 0.0 \\
\hline 30.5 & 52.0 & 11.4 & 4.3 & 0.0 & 17.5 & 0.2 & 6.9 & 1.2 & 0.5 & 0.8 & 1.3 & 0.4 & 0.0 & 1.6 & 2.0 & 0.0 & 0.0 & 0.0 \\
\hline 31.5 & 54.7 & 11.5 & 3.2 & 0.0 & 16.5 & 0.1 & 6.6 & 1.2 & 0.3 & 0.7 & 1.2 & 0.4 & 0.0 & 1.6 & 1.9 & 0.0 & 0.0 & 0.0 \\
\hline 32.5 & 57.1 & 11.5 & 2.4 & 0.0 & 15.7 & 0.1 & 6.3 & 1.2 & 0.2 & 0.7 & 1.2 & 0.4 & 0.0 & 1.6 & 1.8 & 0.0 & 0.0 & 0.0 \\
\hline 33.5 & 59.2 & 11.5 & $\begin{array}{l}2.4 \\
1.7\end{array}$ & 0.0 & 14.8 & 0.0 & 6.0 & 1.2 & 0.1 & 0.6 & $\begin{array}{l}1.2 \\
\text { L }\end{array}$ & 0.3 & 0.0 & $\begin{array}{l}1.0 \\
\text { S }\end{array}$ & $\begin{array}{l}1.0 \\
\end{array}$ & 0.0 & 0.0 & 0.0 \\
\hline 34.5 & 60.8 & 11.5 & $\begin{array}{l}1.1 \\
1.2\end{array}$ & 0.0 & $\begin{array}{l}14.1 \\
\end{array}$ & 0.0 & 5.7 & 1.2 & 0.1 & 0.6 & $\begin{array}{l}1.2 \\
\end{array}$ & 0.3 & 0.0 & $\begin{array}{l}1.0 \\
1.6\end{array}$ & $\begin{array}{l}1.0 \\
1.7\end{array}$ & 0.0 & 0.0 & 0.0 \\
\hline 35.5 & 62.3 & 11.5 & 0.9 & 0.0 & 13.3 & 0.0 & $\begin{array}{l}.11 \\
5.5\end{array}$ & $\begin{array}{l}1.2 \\
1.2\end{array}$ & 0.1 & $\begin{array}{l}0.0 \\
0.5\end{array}$ & $\begin{array}{l}1.2 \\
\end{array}$ & 0.3 & 0.0 & $\begin{array}{l}1.0 \\
1.6\end{array}$ & 1.6 & 0.0 & 0.0 & 0.0 \\
\hline $\begin{array}{l}3.5 \\
36.5\end{array}$ & $\begin{array}{l}03.5 \\
63.6\end{array}$ & 11.5 & 0.6 & 0.0 & $\begin{array}{l}1.3 .5 \\
\end{array}$ & 0.0 & $\begin{array}{l}.5 \\
5.3\end{array}$ & $\begin{array}{l}1.2 \\
1.2\end{array}$ & 0.0 & $\begin{array}{l}.5 \\
0.5\end{array}$ & $\begin{array}{l}1.2 \\
1.2\end{array}$ & $\begin{array}{l}0.3 \\
0.3\end{array}$ & 0.0 & $\begin{array}{l}1.6 \\
1.6\end{array}$ & $\begin{array}{l}1.0 \\
1.6\end{array}$ & 0.0 & 0.0 & 0.0 \\
\hline 37.5 & 64.7 & 11.5 & 0.4 & 0.0 & 11.9 & 0.0 & 5.2 & 1.2 & 0.0 & 0.5 & 1.2 & 0.3 & 0.0 & 1.6 & 1.6 & 0.0 & 0.0 & 0.0 \\
\hline 38.5 & 65.8 & 11.5 & 0.3 & 0.0 & 11.2 & 0.0 & 5.0 & 1.2 & 0.0 & 0.4 & 1.1 & 0.3 & 0.0 & 1.6 & 1.5 & 0.0 & 0.0 & 0.0 \\
\hline 39.5 & 66.8 & 11.5 & 0.2 & 0.0 & 10.6 & 0.0 & 4.8 & 1.2 & 0.0 & 0.4 & 1.1 & 0.2 & 0.0 & 1.6 & 1.5 & 0.0 & 0.0 & 0.0 \\
\hline 40.5 & 67.7 & 11.5 & 0.2 & 0.0 & 10.0 & 0.0 & 4.7 & 1.2 & 0.0 & 0.4 & 1.1 & 0.2 & 0.0 & 1.6 & 1.4 & 0.0 & 0.0 & 0.0 \\
\hline 41.5 & 68.6 & 11.6 & 0.1 & 0.0 & 9.3 & 0.0 & 4.5 & 1.2 & 0.0 & 0.4 & 1.1 & 0.2 & 0.0 & 1.6 & 1.4 & 0.0 & 0.0 & 0.0 \\
\hline 42.5 & 69.4 & 11.6 & 0.1 & 0.0 & 8.7 & 0.0 & 4.3 & 1.2 & 0.0 & 0.3 & 1.1 & 0.2 & 0.0 & 1.6 & 1.4 & 0.0 & 0.0 & 0.0 \\
\hline 43.5 & 70.3 & 11.7 & 0.1 & 0.0 & 8.1 & 0.0 & 4.2 & 1.2 & 0.0 & 0.3 & 1.1 & 0.2 & 0.0 & 1.6 & 1.3 & 0.0 & 0.0 & 0.0 \\
\hline 44.5 & 71.3 & 11.7 & 0.0 & 0.0 & 7.4 & 0.0 & 4.0 & 1.2 & 0.0 & 0.3 & 1.1 & 0.2 & 0.0 & 1.6 & 1.3 & 0.0 & 0.0 & 0.0 \\
\hline 45.5 & 72.2 & 11.7 & 0.0 & 0.0 & 6.7 & 0.0 & 3.8 & 1.2 & 0.0 & 0.3 & 1.1 & 0.2 & 0.0 & 1.6 & 1.3 & 0.0 & 0.0 & 0.0 \\
\hline 46.5 & 73.2 & 11.6 & 0.0 & 0.0 & 6.1 & 0.0 & 3.7 & 1.2 & 0.0 & 0.2 & 1.1 & 0.2 & 0.0 & 1.6 & 1.2 & 0.0 & 0.0 & 0.0 \\
\hline 47.5 & 74.1 & 11.6 & 0.0 & 0.0 & 5.5 & 0.0 & 3.5 & 1.2 & 0.0 & 0.2 & 1.0 & 0.1 & 0.0 & 1.6 & 1.2 & 0.0 & 0.0 & 0.0 \\
\hline 48.5 & 75.0 & 11.5 & 0.0 & 0.0 & 5.0 & 0.0 & 3.4 & 1.2 & 0.0 & 0.2 & 1.0 & 0.1 & 0.0 & 1.5 & 1.1 & 0.0 & 0.0 & 0.0 \\
\hline 49.5 & 75.8 & 11.5 & 0.0 & 0.0 & $\begin{array}{l}3.0 \\
4.4\end{array}$ & 0.0 & $\begin{array}{l}3.4 \\
3.2\end{array}$ & 1.2 & 0.0 & 0.2 & $\begin{array}{l}1.0 \\
1.0\end{array}$ & 0.1 & 0.0 & 1.5 & 1.1 & 0.0 & 0.0 & 0.0 \\
\hline 50.5 & 76.3 & 11.5 & 0.0 & 0.0 & 4.0 & 0.0 & 3.1 & 1.2 & 0.0 & 0.1 & 1.0 & 0.1 & 0.0 & 1.5 & 1.1 & 0.0 & 0.0 & 0.0 \\
\hline 51.5 & 76.7 & 11.5 & 0.0 & 0.0 & 3.7 & 0.0 & 3.1 & 1.2 & 0.0 & 0.1 & 1.0 & 0.1 & 0.0 & 1.5 & 1.1 & 0.0 & 0.0 & 0.0 \\
\hline 52.5 & 77.0 & 11.6 & 0.0 & 0.0 & 3.5 & 0.0 & 3.0 & 1.2 & 0.0 & 0.1 & 1.0 & 0.1 & 0.0 & 1.5 & 1.0 & 0.0 & 0.0 & 0.0 \\
\hline 53.5 & 77.3 & 11.6 & 0.0 & 0.0 & 3.3 & 0.0 & 2.9 & 1.2 & 0.0 & 0.1 & 1.0 & 0.1 & 0.0 & 1.5 & 1.0 & 0.0 & 0.0 & 0.0 \\
\hline
\end{tabular}

Global stratospheric fluorine inventories for 2004-2009
A. T. Brown et al.

Title Page

Abstract

Introduction

Conclusions

References

Tables

Figures

14

4

Back

Close

\section{Full Screen / Esc}

Printer-friendly Version

Interactive Discussion 


\section{ACPD}

13, 16885-16924, 2013

Table A2. The percentage contribution of each species to the total fluorine budget in the latitude bands between $30^{\circ} \mathrm{N}$ and $0^{\circ} \mathrm{N}$.

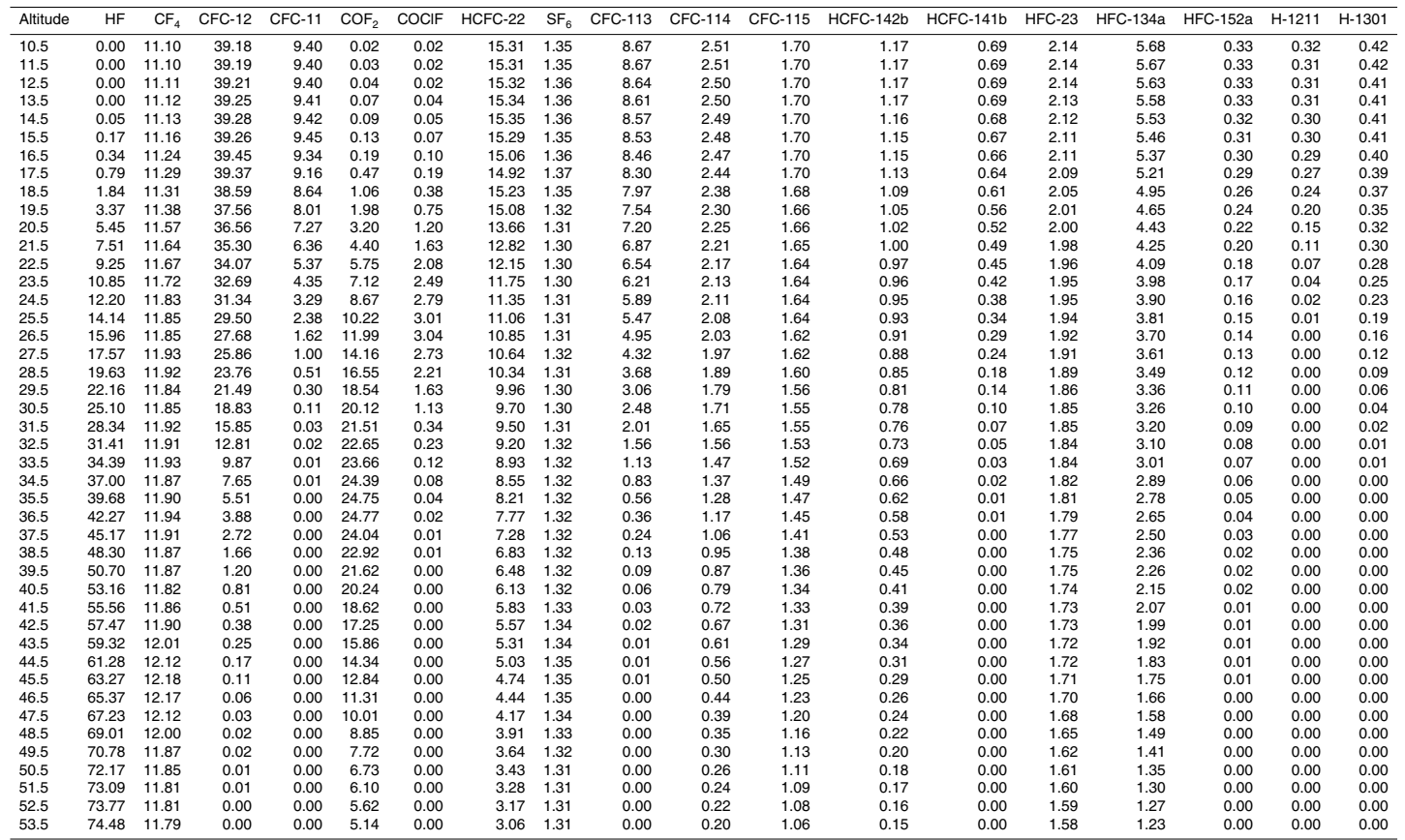

Global stratospheric fluorine inventories for 2004-2009
A. T. Brown et al.

Title Page

Abstract

Introduction

Conclusions

References

Tables

Figures

14

$>$

4

Back

Close

\section{Full Screen / Esc}

Printer-friendly Version

Interactive Discussion 


\section{ACPD}

13, 16885-16924, 2013

Table A3. The percentage contribution of each species to the total fluorine budget in the latitude bands between $0^{\circ} \mathrm{N}$ and $30^{\circ} \mathrm{S}$.

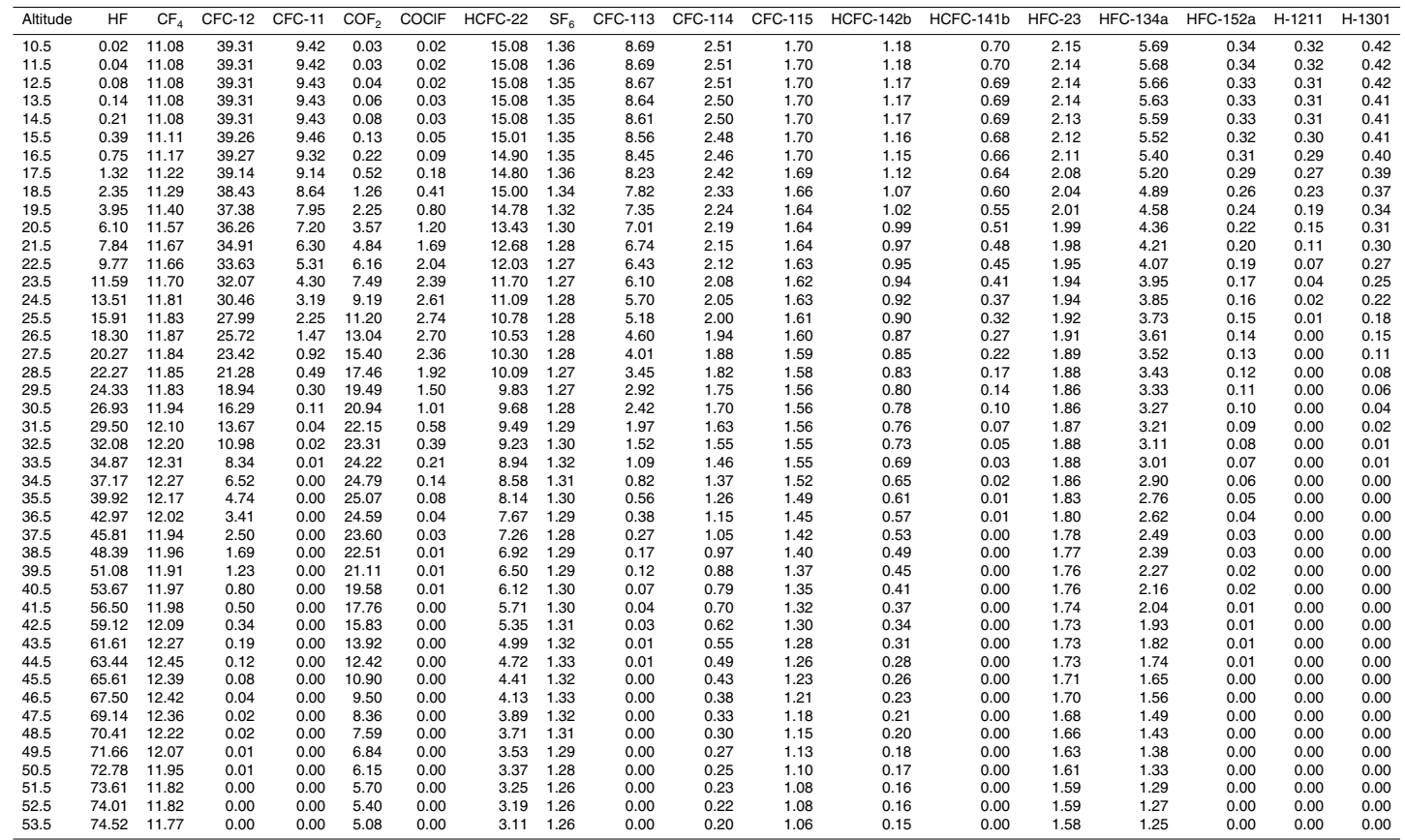

Global stratospheric fluorine inventories for 2004-2009

\section{A. T. Brown et al.}

Title Page

Abstract

Introduction

Conclusions

References

Tables

Figures

14

$>$

4

Back

Full Screen / Esc

Printer-friendly Version

Interactive Discussion 


\section{ACPD}

13, 16885-16924, 2013

Table A4. The percentage contribution of each species to the total fluorine budget in the latitude bands between $30^{\circ} \mathrm{S}$ and $70^{\circ} \mathrm{S}$.

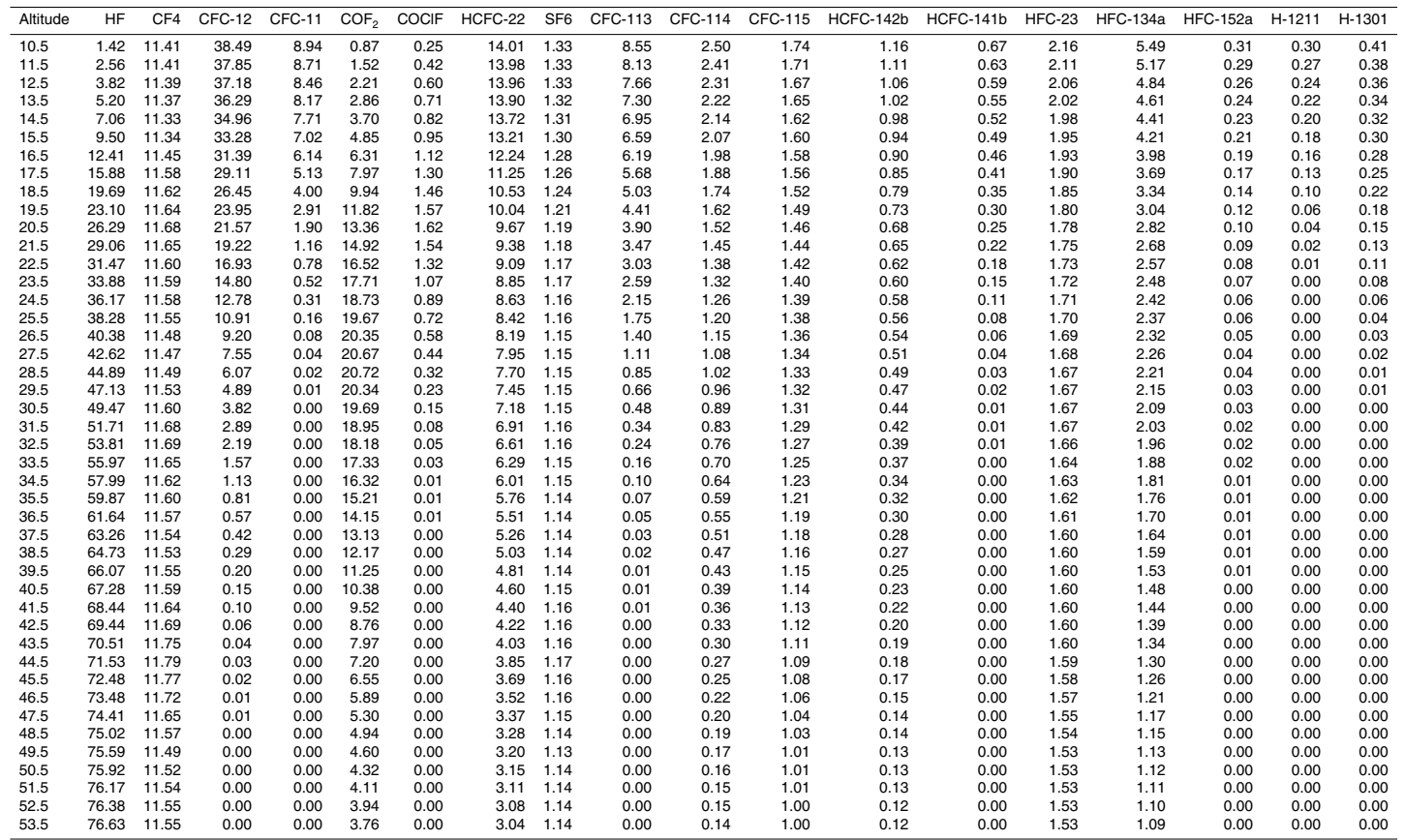

Global stratospheric fluorine inventories for 2004-2009

A. T. Brown et al.

Title Page

Abstract

Introduction

Conclusions

References

Tables

Figures

14

$>$

4

Back

Full Screen / Esc

Printer-friendly Version

Interactive Discussion

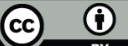



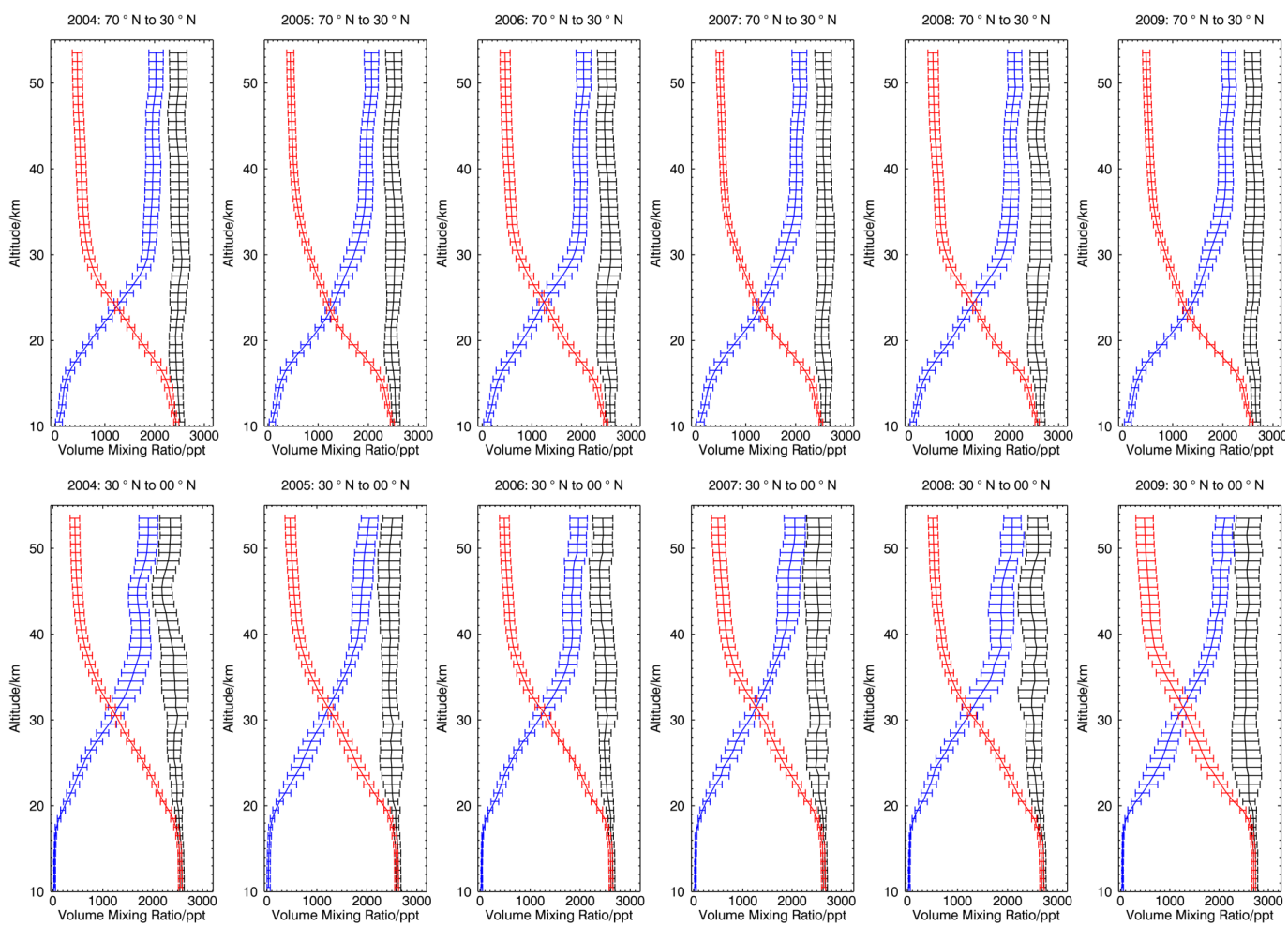

\section{ACPD}

13, 16885-16924, 2013

Global stratospheric fluorine inventories for 2004-2009
A. T. Brown et al.

\section{Title Page}

Abstract

Introduction

Conclusions

References

Tables

Figures

1<

$>1$

4

Back

>

Close

\section{Full Screen / Esc}

Fig. 1. The fluorine budgets from 2004 to 2009 in latitude band $30-70^{\circ} \mathrm{N}$ and $0-30^{\circ} \mathrm{N}$ (black). The inorganic (blue) and organic (red) fluorine profiles are also shown. The error bars are the result of combinations of standard deviations of the mean profiles of the relevant fluorine containing species.

Printer-friendly Version

Interactive Discussion 

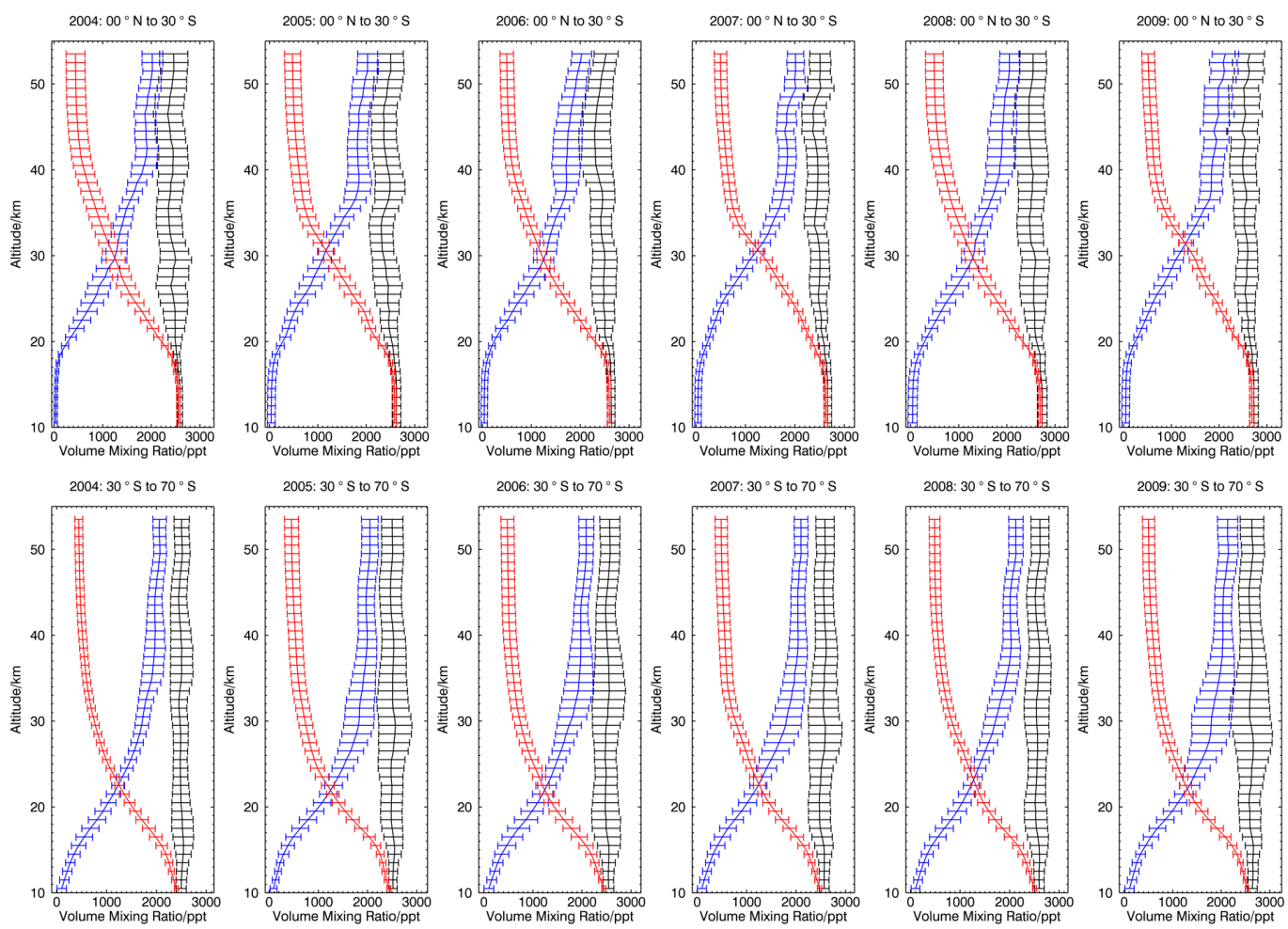

\section{ACPD}

13, 16885-16924, 2013

Global stratospheric fluorine inventories for 2004-2009
A. T. Brown et al.

Title Page

4

\section{$>$}

\section{Close}

\section{Full Screen / Esc}

Printer-friendly Version

Interactive Discussion

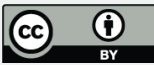




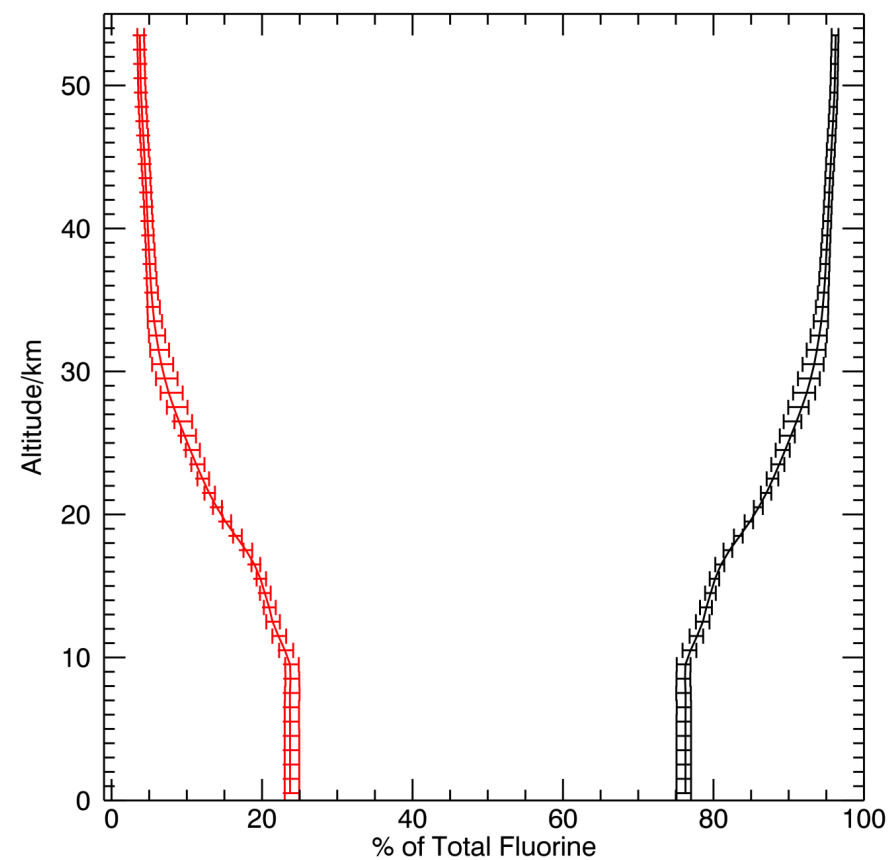

Global stratospheric fluorine inventories for 2004-2009

A. T. Brown et al.

Title Page

Abstract

Conclusions

Tables

14

4

Back

Introduction

References

Figures

>I

$>$

Full Screen / Esc

Printer-friendly Version

Interactive Discussion

Fig. 3. The mean percentage contribution of ACE-FTS (black) and SLIMCAT (red) to the total fluorine VMR for all years between $70-30^{\circ} \mathrm{N}$. The error bars are the maximum or minimum single contribution to the total fluorine percentage from these years. 

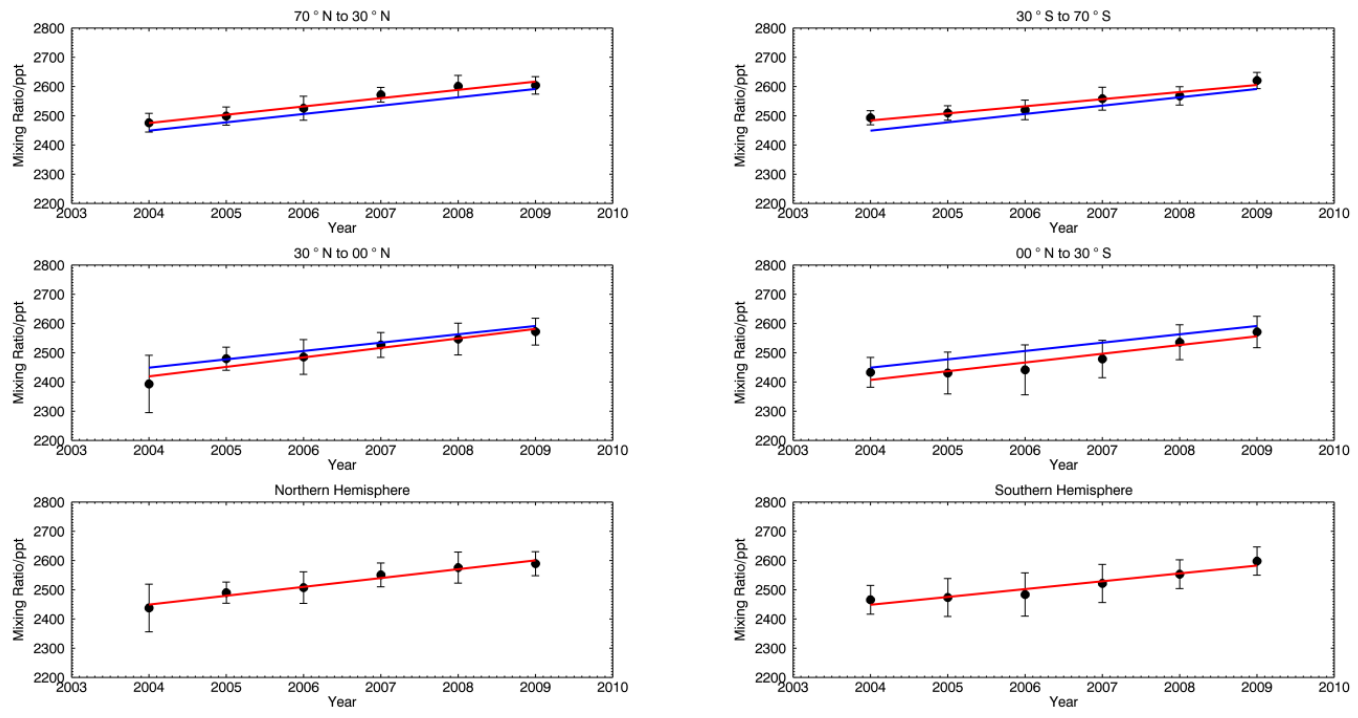

Fig. 4. The trends in the mean total stratospheric fluorine (ppt) between 2004 and 2009. The red line represents the line of best fit for the mean stratospheric total fluorine volume mixing ratio (the black circles). The blue line is the global trend in mean total stratospheric fluorine. The error bars shown in the plots are calculated from the standard deviation of the data used to calculate the mean total fluorine VMRs.
Global stratospheric fluorine inventories for 2004-2009

A. T. Brown et al.

\section{Title Page}

Abstract

Introduction

Conclusions

References

Tables

Figures

14

$>1$

4

Back

$\triangleright$

Close

Full Screen / Esc

Printer-friendly Version

Interactive Discussion 


\section{ACPD}

13, 16885-16924, 2013

Global stratospheric fluorine inventories

for 2004-2009

\section{A. T. Brown et al.}

\section{Title Page}
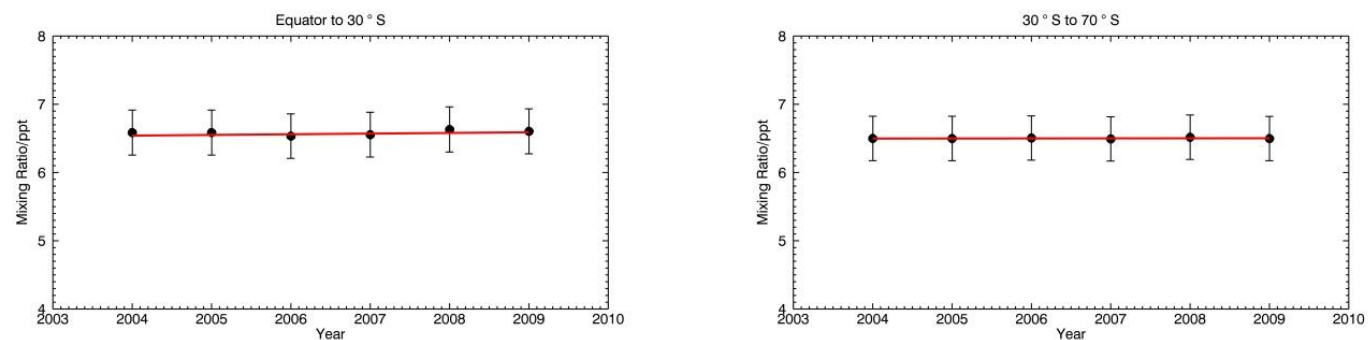

Fig. 5. The trends in the GWP-weighted total fluorine mean between 2004 and 2009. The red line represents the line of best fit for the GWP-weighted mean volume mixing ratio (the black circles). The error bars shown in the plots are calculated from the weighted standard deviation of the data used to calculate the means.
Conclusions

Tables

References

Figures

14

$>1$

4

Back

Close

\section{Full Screen / Esc}

Printer-friendly Version

Interactive Discussion 